\title{
LEVEL II SCOUR ANALYSIS FOR BRIDGE 4 (MAIDTH00070004) on TOWN HIGHWAY 7, crossing CUTLER MILL BROOK, MAIDSTONE, VERMONT
}

Open-File Report 97-760

Prepared in cooperation with

VERMONT AGENCY OF TRANSPORTATION

and

FEDERAL HIGHWAY ADMINISTRATION

U.S. Department of the Interior

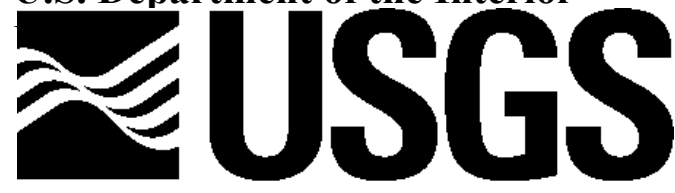

science for a changing world 


\section{LEVEL II SCOUR ANALYSIS FOR BRIDGE 4 (MAIDTH00070004) on TOWN HIGHWAY 7, crossing CUTLER MILL BROOK, MAIDSTONE, VERMONT}

By LORA K. STRIKER AND LAURA MEDALIE

U.S. Geological Survey Open-File Report 97-760

Prepared in cooperation with

VERMONT AGENCY OF TRANSPORTATION

and

FEDERAL HIGHWAY ADMINISTRATION 


\title{
U.S. DEPARTMENT OF THE INTERIOR BRUCE BABBITT, Secretary
}

\author{
U.S. GEOLOGICAL SURVEY \\ Mark Schaefer, Acting Director
}

For additional information write to:

District Chief

U.S. Geological Survey 361 Commerce Way

Pembroke, NH 03275-3718
Copies of this report may be purchased from:

U.S. Geological Survey

Branch of Information Services

Open-File Reports Unit

Box 25286

Denver, CO 80225-0286 


\section{CONTENTS}

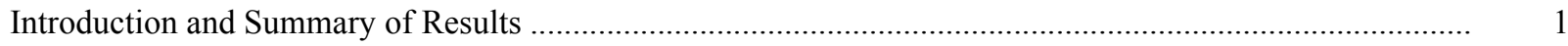

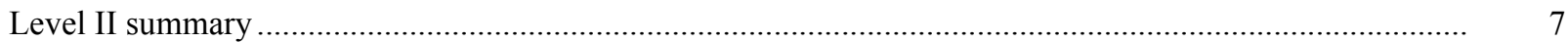

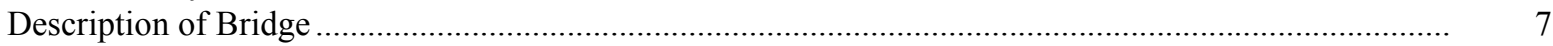

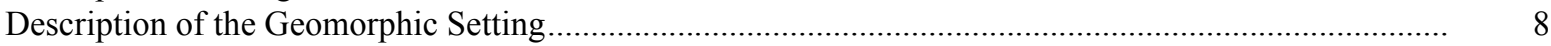

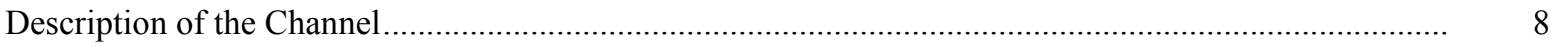

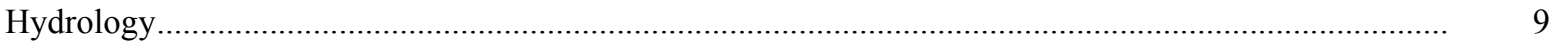

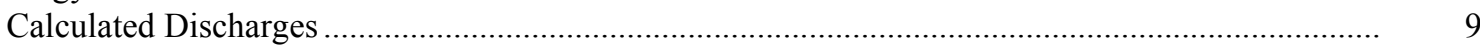

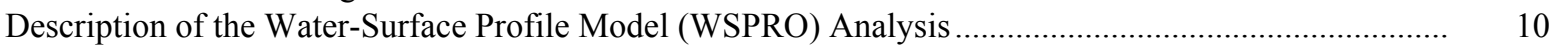

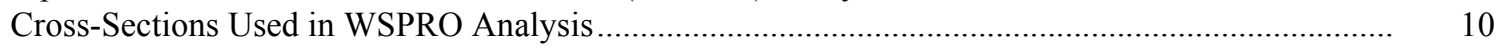

Data and Assumptions Used in WSPRO Model ...................................................................... 11

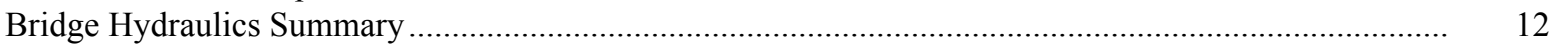

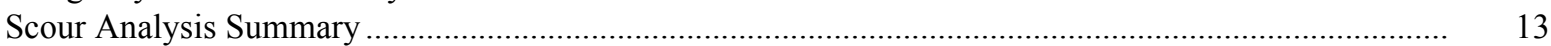

Special Conditions or Assumptions Made in Scour Analysis ...................................................... 13

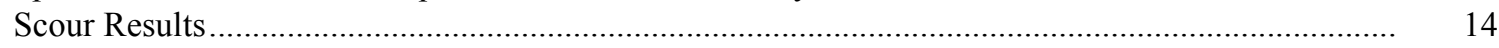

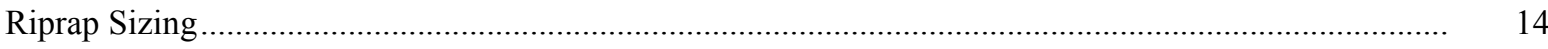

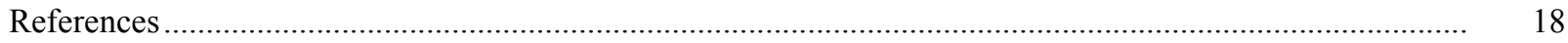

Appendixes:

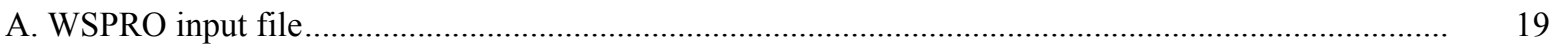

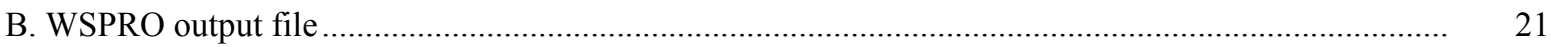

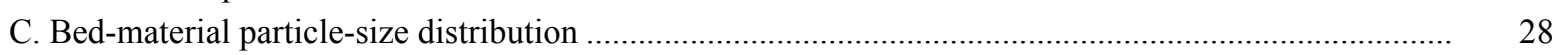

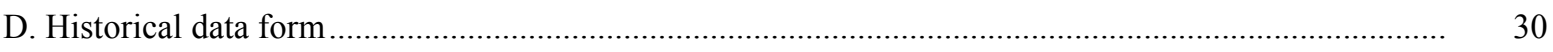

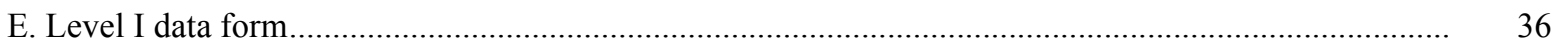

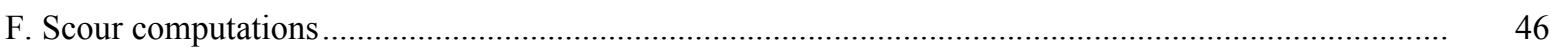

\section{FIGURES}

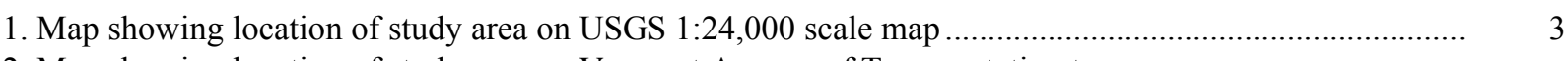

2. Map showing location of study area on Vermont Agency of Transportation town
highway map

3. Structure MAIDTH00070004 viewed from upstream (July 19, 1995) .................................................... 5

4. Downstream channel viewed from structure MAIDTH00070004 (July 19, 1995) ................................ 5

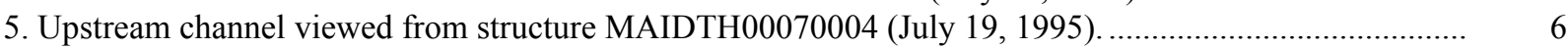

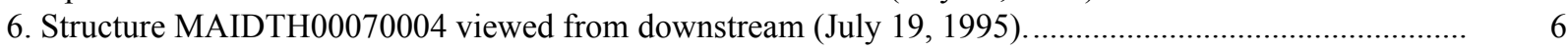

7. Water-surface profiles for the 100- and 500-year discharges at structure

MAIDTH00070004 on Town Highway 7, crossing Cutler Mill Brook,

Maidstone, Vermont.

8. Scour elevations for the 100- and 500-year discharges at structure

MAIDTH00070004 on Town Highway 7, crossing Cutler Mill Brook,

Maidstone, Vermont. 5 5

6

.




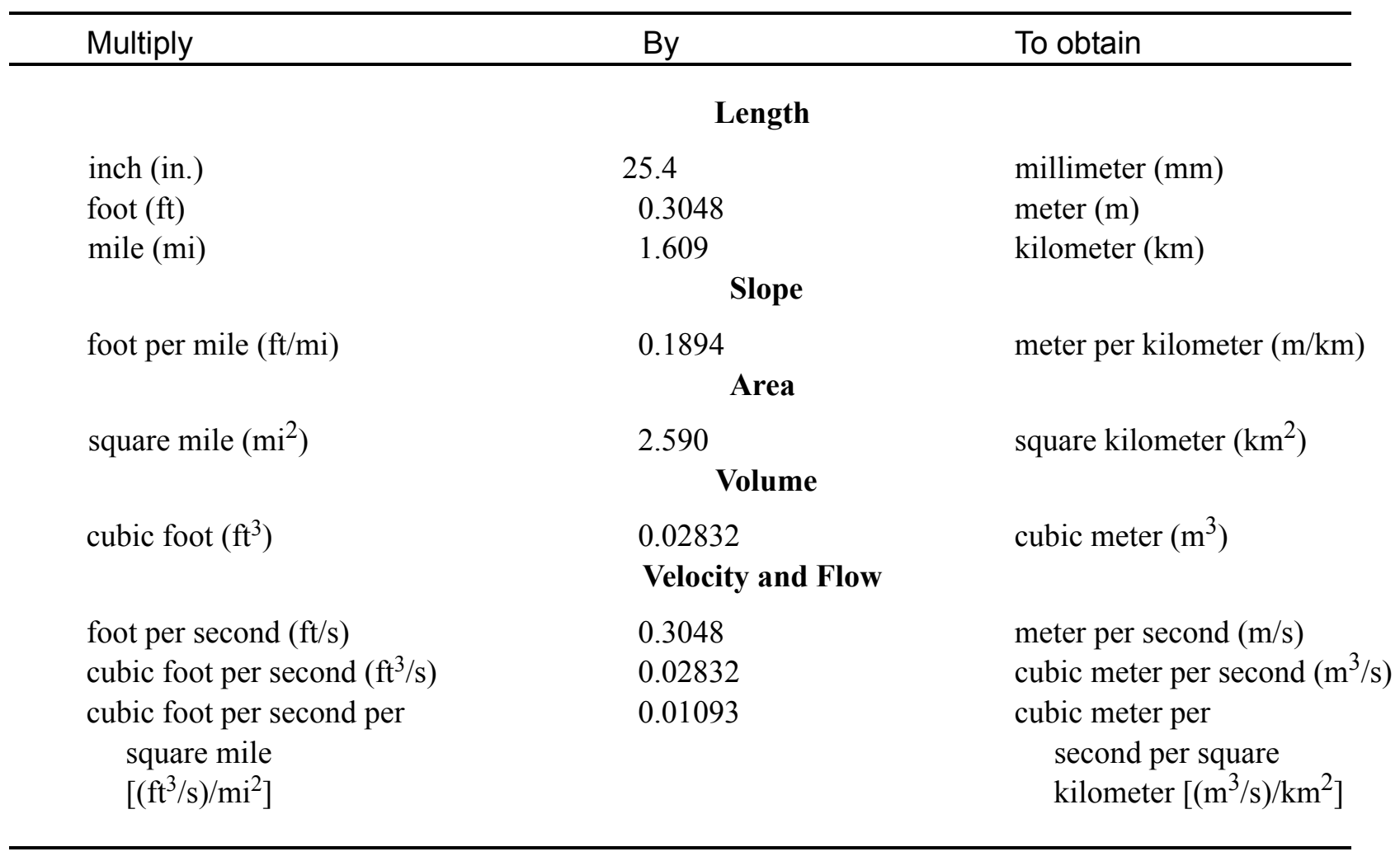

\section{OTHER ABBREVIATIONS}

$\begin{array}{lrlr}\mathrm{BF} & \text { bank full } & \text { LWW } & \text { left wingwall } \\ \mathrm{cfs} & \text { cubic feet per second } & \text { MC } & \text { main channel } \\ \mathrm{D}_{50} & \text { median diameter of bed material } & \text { RAB } & \text { right abutment } \\ \mathrm{DS} & \text { downstream } & \text { RABUT } & \text { face of right abutment } \\ \mathrm{elev} & \text { elevation } & \text { RB } & \text { right bank } \\ \mathrm{f} / \mathrm{p} & \text { flood plain } & \text { ROB } & \text { right overbank } \\ \mathrm{ft}^{2} & \text { square feet } & \text { RWW } & \text { right wingwall } \\ \mathrm{ft} / \mathrm{ft} & \text { feet per foot } & \text { TH } & \text { town highway } \\ \mathrm{JCT} & \text { junction } & \text { UB } & \text { under bridge } \\ \mathrm{LAB} & \text { left abutment } & \text { US } & \text { upstream } \\ \mathrm{LABUT} & \text { face of left abutment } & \text { USGS } & \text { United States Geological Survey } \\ \mathrm{LB} & \text { left bank } & \text { VTAOT Vermont Agency of Transportation } \\ \mathrm{LOB} & \text { left overbank } & \text { WSPRO } & \text { water-surface profile model }\end{array}$

In this report, the words "right" and "left" refer to directions that would be reported by an observer facing downstream. Sea level: In this report, "sea level" refers to the National Geodetic Vertical Datum of 1929-- a geodetic datum derived from a general adjustment of the first-order level nets of the United States and Canada, formerly called Sea Level Datum of 1929.

In the appendices, the above abbreviations may be combined. For example, USLB would represent upstream left bank. 


\title{
LEVEL II SCOUR ANALYSIS FOR BRIDGE 4 (MAIDTH00070004) ON TOWN HIGHWAY 7, CROSSING CUTLER MILL BROOK, MAIDSTONE, VERMONT
}

\author{
By Lora K. Striker and Laura Medalie
}

\section{INTRODUCTION AND SUMMARY OF RESULTS}

This report provides the results of a detailed Level II analysis of scour potential at structure MAIDTH00070004 on Town Highway 7 crossing the Cutler Mill Brook, Maidstone, Vermont (figures 1-8). A Level II study is a basic engineering analysis of the site, including a quantitative analysis of stream stability and scour (U.S. Department of Transportation, 1993). Results of a Level I scour investigation also are included in Appendix E of this report. A Level I investigation provides a qualitative geomorphic characterization of the study site. Information on the bridge, gleaned from Vermont Agency of Transportation (VTAOT) files, was compiled prior to conducting Level I and Level II analyses and is found in Appendix D.

The site is in the White Mountain section of the New England physiographic province in northeastern Vermont. The $18.1-\mathrm{mi}^{2}$ drainage area is in a predominantly rural and forested basin. In the vicinity of the study site, the surface cover is predominantly shrub and brushland.

In the study area, the Cutler Mill Brook has a non-incised, meandering channel with local braiding and a slope of approximately $0.004 \mathrm{ft} / \mathrm{ft}$, an average channel top width of $43 \mathrm{ft}$ and an average bank height of $2 \mathrm{ft}$. The channel bed material ranges from sand to cobble with a median grain size $\left(\mathrm{D}_{50}\right)$ of $27.6 \mathrm{~mm}(0.091 \mathrm{ft})$. The geomorphic assessment at the time of the Level I and Level II site visit on July 19, 1995, indicated that the reach was laterally unstable due to large meanders in the channel.

The Town Highway 7 crossing of the Cutler Mill Brook is a 25-ft-long, one-lane bridge consisting of one 22-foot concrete span (Vermont Agency of Transportation, written communication, August 5, 1994). The opening length of the structure parallel to the bridge face is $21.7 \mathrm{ft}$. The bridge is supported by vertical, concrete abutments with wingwalls. The channel is skewed approximately 20 degrees to the opening while the opening-skew-toroadway is 0 degrees. 
A scour hole $2.0 \mathrm{ft}$ deeper than the mean thalweg depth was observed along the left abutment during the Level I assessment. The only scour protection measure at the site was type- 2 stone fill (less than 36 inches diameter) along both banks upstream, along the entire base length of the upstream left wingwall, and along the upstream end of the upstream right wingwall. Additional details describing conditions at the site are included in the Level II Summary and Appendices D and E.

Scour depths and recommended rock rip-rap sizes were computed using the general guidelines described in Hydraulic Engineering Circular 18 (Richardson and others, 1995) for the 100- and 500-year discharges. In addition, the incipient roadway-overtopping discharge was determined and analyzed as another potential worst-case scour scenario. Total scour at a highway crossing is comprised of three components: 1) long-term streambed degradation; 2) contraction scour (due to accelerated flow caused by a reduction in flow area at a bridge) and; 3 ) local scour (caused by accelerated flow around piers and abutments). Total scour is the sum of the three components. Equations are available to compute depths for contraction and local scour and a summary of the results of these computations follows.

Contraction scour for all modelled flows ranged from 2.2 to $4.2 \mathrm{ft}$. The worst-case contraction scour occurred at the 500-year discharge. Abutment scour ranged from 5.7 to $12.4 \mathrm{ft}$. The worst-case abutment scour occurred at the 500-year discharge. Additional information on scour depths and depths to armoring are included in the section titled "Scour Results". Scoured-streambed elevations, based on the calculated scour depths, are presented in tables 1 and 2. A cross-section of the scour computed at the bridge is presented in figure 8. Scour depths were calculated assuming an infinite depth of erosive material and a homogeneous particle-size distribution.

It is generally accepted that the Froehlich equation (abutment scour) gives "excessively conservative estimates of scour depths" (Richardson and others, 1995, p. 47). Usually, computed scour depths are evaluated in combination with other information including (but not limited to) historical performance during flood events, the geomorphic stability assessment, existing scour protection measures, and the results of the hydraulic analyses. Therefore, scour depths adopted by VTAOT may differ from the computed values documented herein. 


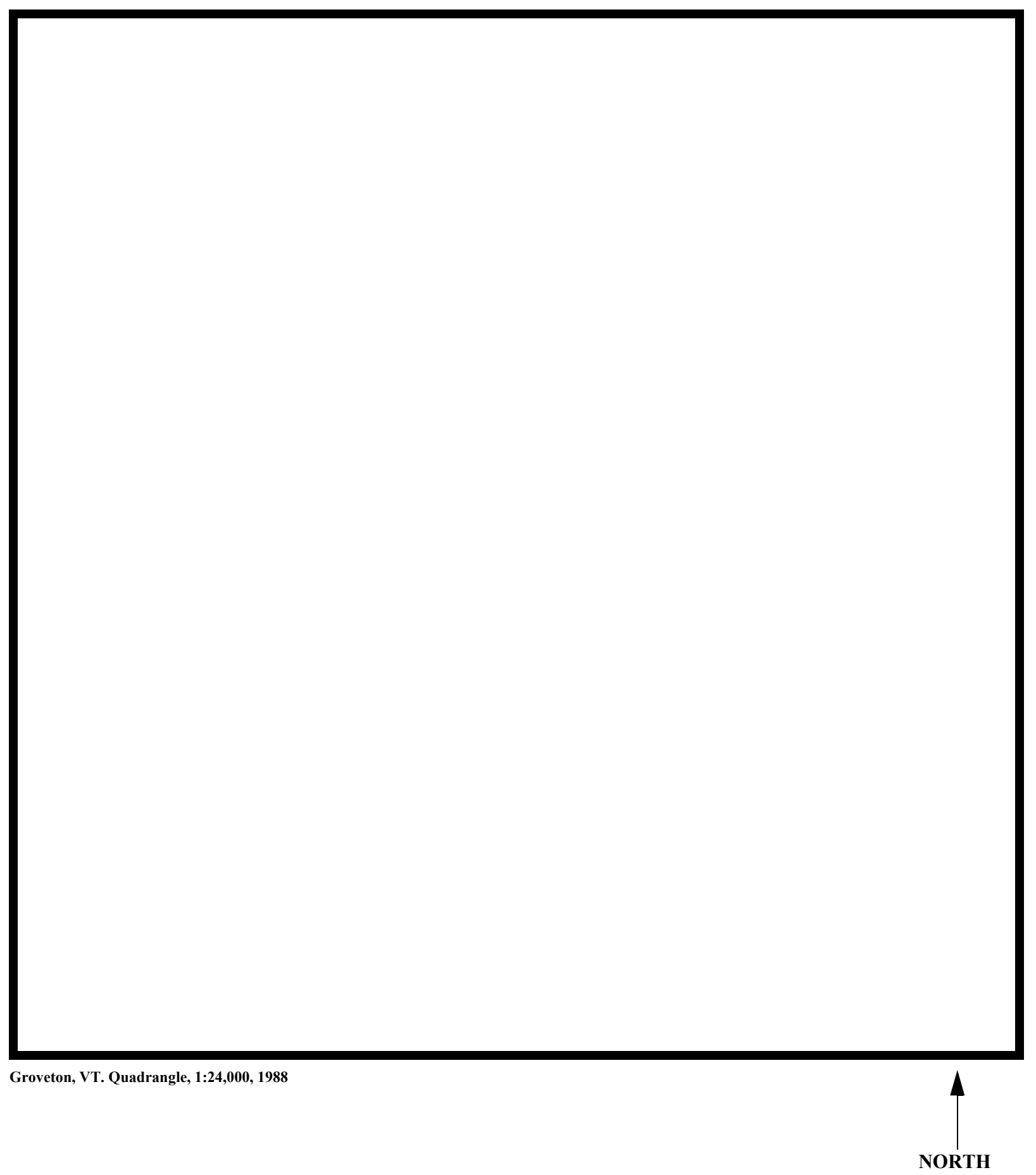

Figure 1. Location of study area on USGS 1:24,000 scale map. 
Figure 2. Location of study area on Vermont Agency of Transportation town highway map. 

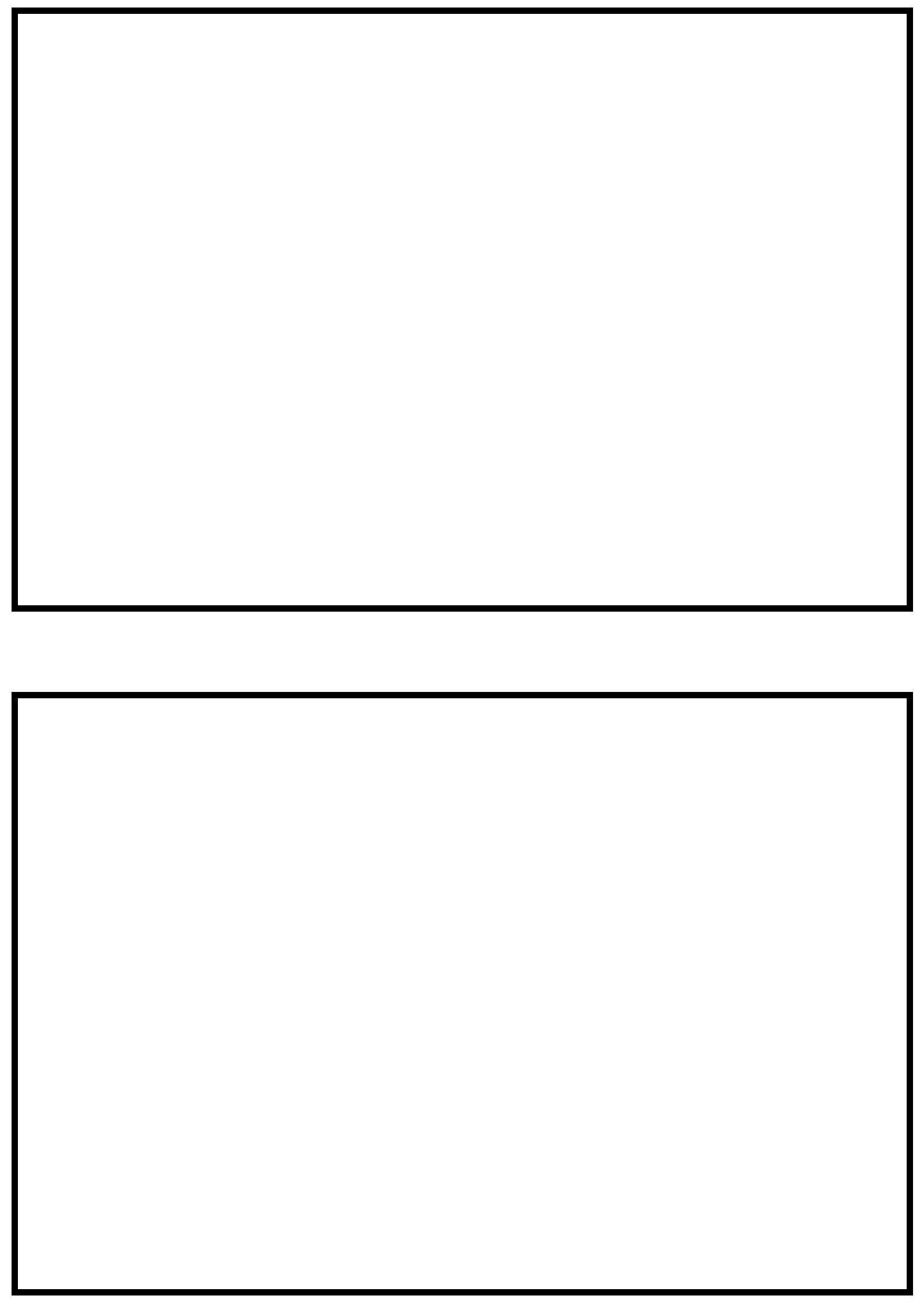

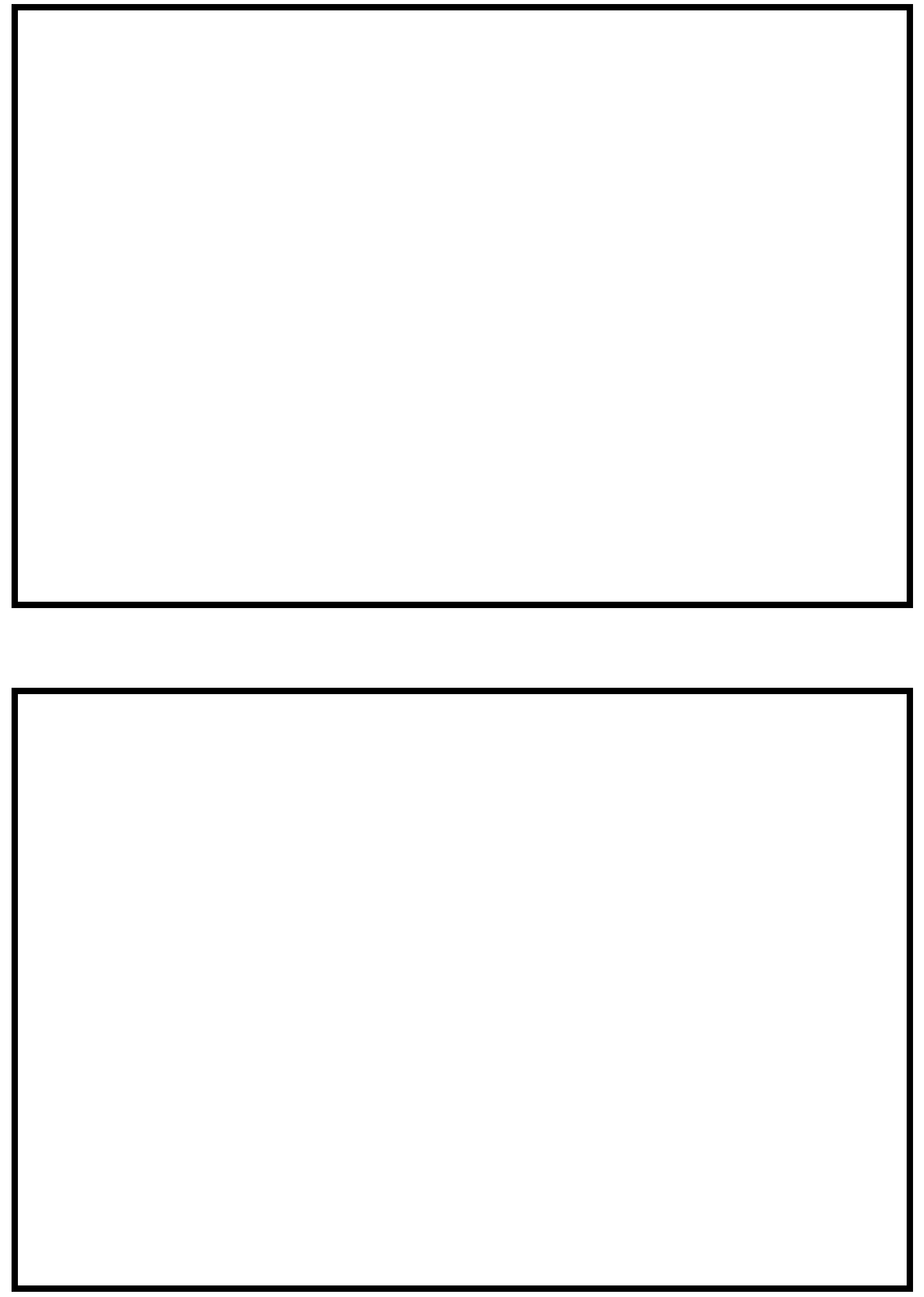


\section{LEVEL II SUMMARY}

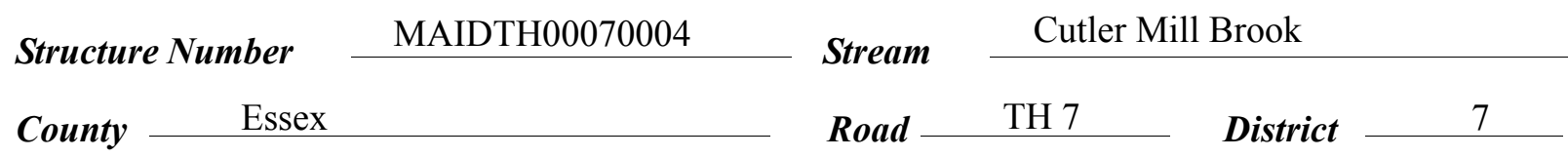

\section{Description of Bridge}

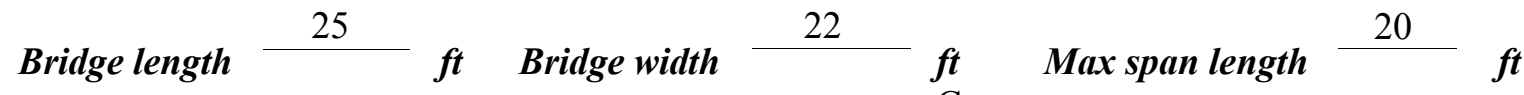
Alignment of bridge to road (on curve or straight)

Abutment type Vertical, concrete

Stone fill on abutment?

$$
\text { No }
$$

\section{Embankment type} Curve

\section{Dato af incnortion} Type-2, along the entire base length of the upstream left wingwall and

\section{Sloping}

$07 / 19 / 95$ at the upstream end of the upstream right wingwall.

Abutments and wingwalls are concrete. There is a two

foot deep scour hole along the left abutment.

Is bridge skewed to flood flow according to $\mathrm{Y} \quad$ 'survey?
There is a large channel bend in the upstream reach. A sçour hole has developed where the flow
impacts the left abutment.

Debris accumulation on bridge at time of Level I or Level II site visit:

\begin{tabular}{|c|c|c|c|}
\hline & $\begin{array}{c}\text { Date of insnortion } \\
07 / 19 / 95 \\
\end{array}$ & $\begin{array}{l}\text { Percent of alsmunt } \\
\text { blocked inortzontatly }\end{array}$ & $\begin{array}{l}\text { Percent of } 0 \\
\text { blocked verticatty }\end{array}$ \\
\hline & $07 / 19 / 95$ & 0 & 0 \\
\hline Level II & Low. & & \\
\hline
\end{tabular}

\section{Potential for debris}

Heavy vegetation 10 to $15 \mathrm{ft}$ in height along the banks upstream is noted as an obstruction to Doscriho anv, foaturos noar ar at tho hridoo that mav, affort flow, (includo ahsorvation dato) flow, 07/19/95. 


\section{Description of the Geomorphic Setting}

General topography The channel is located within a narrow flood plain with a steep valley wall on the right.

Geomorphic conditions at bridge site: downstream (DS), upstream (US)

Date of inspection $\quad 07 / 19 / 95$

DS left: $\quad$ Moderately sloping channel bank to a narrow flood plain

DS right: $\quad$ Steep channel bank to a narrow flood plain

US left: $\quad$ Steep channel bank to a narrow flood plain

US right: $\quad$ Moderately sloped channel bank to a narrow flood plain

\section{Description of the Channel}

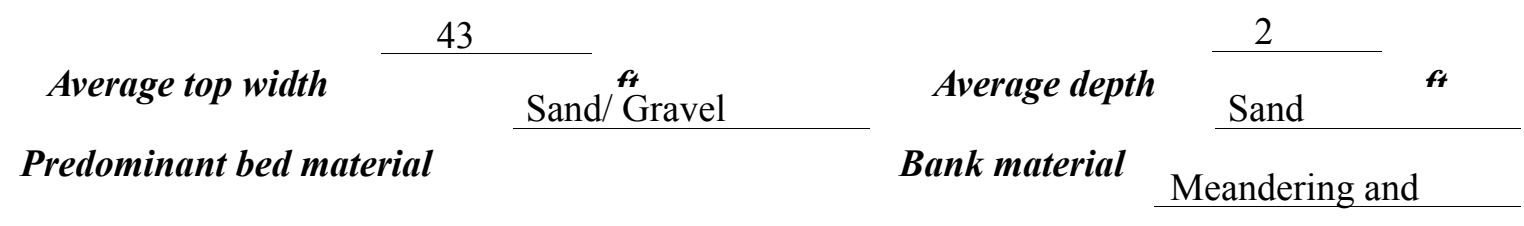

laterally unstable with alluviai channel boundaries and a narrow flöod plain.

$07 / 19 / 95$

Vegetative co ${ }^{1}$ Brush and a few small trees

DS left: $\quad$ Brush and a few small trees

DS right: $\quad$ Brush and a few small trees to a pasture overbank

US left: $\quad$ Brush to a pasture overbank

US right:

$\mathrm{N}$

Do banks appear stable? There is a large, bend in the upstream reach and an additional bend that impacts the left abutment.

None, 07/19/96.

Describe any obstructions in channel and date of observation. 


\title{
Hydrology
}

Drainage area $\frac{18.1}{\boldsymbol{m i}^{2}}$

Percentage of drainage area in physiographic provinces: (approximate)

Physiographic province/section

New England/White Mountain
Percent of drainage area 100

\begin{abstract}
Is drainage area considered rural or urban? Rural Describe any significant urbanization: None.
\end{abstract}

Is there a

Is there a USGS gage on the stream of interest? $--$

\section{USGS gage description}

USGS gage number

Gage drainage area $\mathrm{mi}^{2}$

No

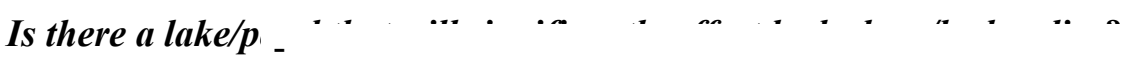

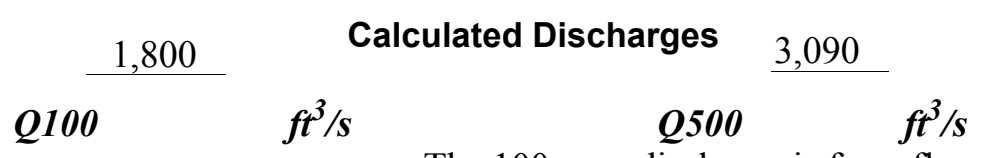

The 100-year discharge is from flood frequency

estimates ayailable from the VTAOT database which were extended graphically to the 500-year discharge. The values used were within a range defined by flood frequency curves developed from several empirical methods (Benson, 1962; Johnson and Tasker, 1974; FHWA, 1983; Potter, 1957a\&b; Talbot, 1887). 


\section{Description of the Water-Surface Profile Model (WSPRO) Analysis}

Datum for WSPRO analysis (USGS survey, sea level, VTAOT plans)

VTAOT

Datum tie between USGS survey and VTAOT plans

USGS and VTAOT datums are

tied by survey points on the top of the upstream wing walls.

Description of reference marks used to determine USGS datum. $\quad$ RM1 is a chiseled X on

top of the upstream end of the right abutment (elev. $502.81 \mathrm{ft}$, arbitrary survey datum). RM2 is a

chiseled X on top of the downstream end of the left abutment

(elev. $502.60 \mathrm{ft}$, arbitrary survey datum).

\section{Cross-Sections Used in WSPRO Analysis}

\begin{tabular}{|c|c|c|c|}
\hline${ }^{1}$ Cross-section & $\begin{array}{c}\text { Section } \\
\text { Reference } \\
\text { Distance } \\
\text { (SRD) in feet }\end{array}$ & $\begin{array}{c}{ }^{2} \text { Cross-section } \\
\text { development }\end{array}$ & Comments \\
\hline EXITX & -26 & 1 & Exit section \\
\hline FULLV & 0 & 2 & $\begin{array}{l}\text { Downstream Full-valley } \\
\text { section (Templated from } \\
\text { EXITX) }\end{array}$ \\
\hline BRIDG & 0 & 1 & Bridge section \\
\hline RDWAY & 11 & 1 & Road Grade section \\
\hline APPRO & 39 & 1 & Approach section \\
\hline
\end{tabular}

${ }^{1}$ For location of cross-sections see plan-view sketch included with Level I field form, Appendix E. For more detail on how cross-sections were developed see WSPRO input file. 


\section{Data and Assumptions Used in WSPRO Model}

Hydraulic analyses of the reach were done by use of the Federal Highway Administration's WSPRO step-backwater computer program (Shearman and others, 1986, and Shearman, 1990). The analyses reported herein reflect conditions existing at the site at the time of the study. Furthermore, in the development of the model it was necessary to assume no accumulation of debris or ice at the site. Results of the hydraulic model are presented in the Bridge Hydraulic Summary, Appendix B, and figure 7.

Channel roughness factors (Manning's “ $n$ ”) used in the hydraulic model were estimated using field inspections at each cross section following the general guidelines described by Arcement and Schneider (1989). Final adjustments to the values were made during the modelling of the reach. Channel " $n$ " values for the reach ranged from 0.035 to 0.050 , and overbank " $n$ " values ranged from 0.055 to 0.095 .

Normal depth at the exit section (EXITX) was assumed as the starting water surface. This depth was computed by use of the slope-conveyance method outlined in the user's manual for WSPRO (Shearman, 1990). The slope used was $0.0038 \mathrm{ft} / \mathrm{ft}$, which was estimated from the topographic map (U.S. Geological Survey, 1988).

The approach section (APPRO) was surveyed one bridge length upstream of the upstream face as recommended by Shearman and others (1986). This location provides a consistent method for determining scour variables. 


\section{Bridge Hydraulics Summary}

$\begin{array}{llll}\text { Average bridge embankment elevation } & 502.7 & f t \\ \text { Average low steel elevation } & 501.0 & \boldsymbol{f t}\end{array}$

100-year discharge $1,800 \quad \mathrm{ft}^{3} / \mathrm{s}$

Water-surface elevation in bridge opening $\quad 501.0 \quad f t$

Road overtopping? ___ Y Discharge over road _ـ $357 \quad \mathrm{ft}^{3} / \mathrm{s}$

Area of flow in bridge opening $\quad 165 \quad \mathrm{ft}^{2}$

Average velocity in bridge opening $\quad \begin{array}{lll}8.9 & \mathrm{ft} / \mathrm{s}\end{array}$

Maximum WSPRO tube velocity at bridge $\quad 12.4 \mathrm{ft} / \mathrm{s}$

Water-surface elevation at Approach section with bridge 502.9

Water-surface elevation at Approach section without bridge $\quad 500.3$

Amount of backwater caused by bridge

$2.6 i$

500-year discharge $\quad 3,090 \quad \mathrm{ft}^{3} / \mathrm{s}$

Water-surface elevation in bridge opening $\quad 501.2 \mathrm{ft}$

Road overtopping? ___ Y Discharge over road __ 1,320 $\mathrm{ft}^{3} / \mathbf{s}$

Area of flow in bridge opening $\quad 166 \quad \mathrm{ft}^{2}$

Average velocity in bridge opening $10.4 \mathrm{ft} / \mathrm{s}$

Maximum WSPRO tube velocity at bridge 12.2 , 's

Water-surface elevation at Approach section with bridge 503.8

Water-surface elevation at Approach section without bridge $\quad 501.2$

Amount of backwater caused by bridge $\quad 2.6, t$

Incipient overtopping discharge $\quad 1,270 \quad \mathrm{ft}^{3} / \mathrm{s}$

Water-surface elevation in bridge opening $498.7 \quad t$

Area of flow in bridge opening

$117 \boldsymbol{f t}^{2}$

Average velocity in bridge opening $10.8 \quad \mathrm{ft} / \mathrm{s}$

Maximum WSPRO tube velocity at bridge $13.7 \mathrm{ft} / \mathrm{s}$

Water-surface elevation at Approach section with bridge

Water-surface elevation at Approach section without bridge

501.1

Amount of backwater caused by bridge $\quad 1.3$, t 


\section{Scour Analysis Summary}

\section{Special Conditions or Assumptions Made in Scour Analysis}

Scour depths were computed using the general guidelines described in Hydraulic Engineering Circular 18 (Richardson and others, 1995). Scour depths were calculated assuming an infinite depth of erosive material and a homogeneous particle-size distribution. The results of the scour analysis are presented in tables 1 and 2 and a graph of the scour depths is presented in figure 8 .

Contraction scour for the incipient roadway-overtopping discharge was computed by use of the Laursen clear-water contraction scour equation (Richardson and others, 1995, p. 32 , equation 20). At this site, the 100-year discharge resulted in unsubmerged orifice flow while the 500-year discharge resulted in submerged orifice flow. Contraction scour at bridges with orifice flow is best estimated by use of the Chang pressure-flow scour equation (oral communication, J. Sterling Jones, October 4, 1996). Thus, contraction scour for these discharges was computed by use of the Chang equation (Richardson and others, 1995, p. 145-146).

For comparison, contraction scour for the discharges resulting in orifice flow was also computed by use of the Laursen clear-water contraction scour equation and the Umbrell pressure-flow equation (Richardson and others, 1995, p. 144) and presented in Appendix F. Furthermore, for those discharges resulting in unsubmerged orifice flow, contraction scour was computed by substituting estimates for the depth of flow at the downstream bridge face in the contraction scour equations. Results with respect to these substitutions are provided in Appendix F.

Scour at the abutments was computed by use of the HIRE equation (Richardson and others, 1995, p. 49, equation 29) because the HIRE equation is recommended when the length to depth ratio of the embankment blocking flow exceeds 25. Variables for the HIRE equation include the Froude number of the flow approaching the embankments, the length of the embankment blocking flow, and the depth of flow approaching the embankment less any roadway overtopping. 


\section{Scour Results}

\section{0-yr discharge 500-yr discharge}

Contraction scour:

(Scour depths in feet)

Main channel

Live-bed scour

Clear-water scour

Depth to armoring

Left overbank

Right overbank

Local scour:

Abutment scour

Left abutment

7.8

8.6

6.3

$9.5-$

$12.4-$

$5.7-$

Right abutment

Pier scour

Pier 1

Pier 2

Pier 3

\section{Abutments:}

Left abutment

Right abutment

Piers:

Pier 1

Pier 2

overtopping discharge

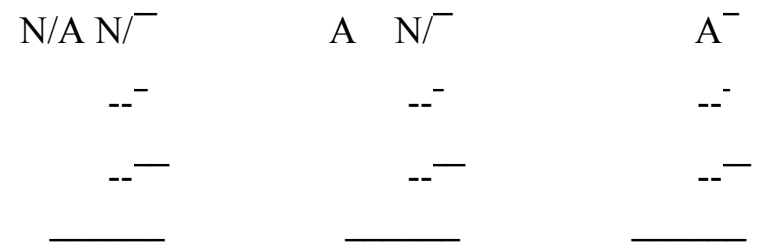

Riprap Sizing

Incipient overtopping 100-yr discharge 500-yrdischarge discharge

2.0

2.0

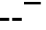

$--$

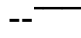
( $D_{50}$ in feet)

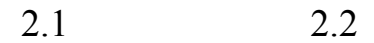

\begin{tabular}{ll}
2.1 & 2.2 \\
\hline
\end{tabular} 


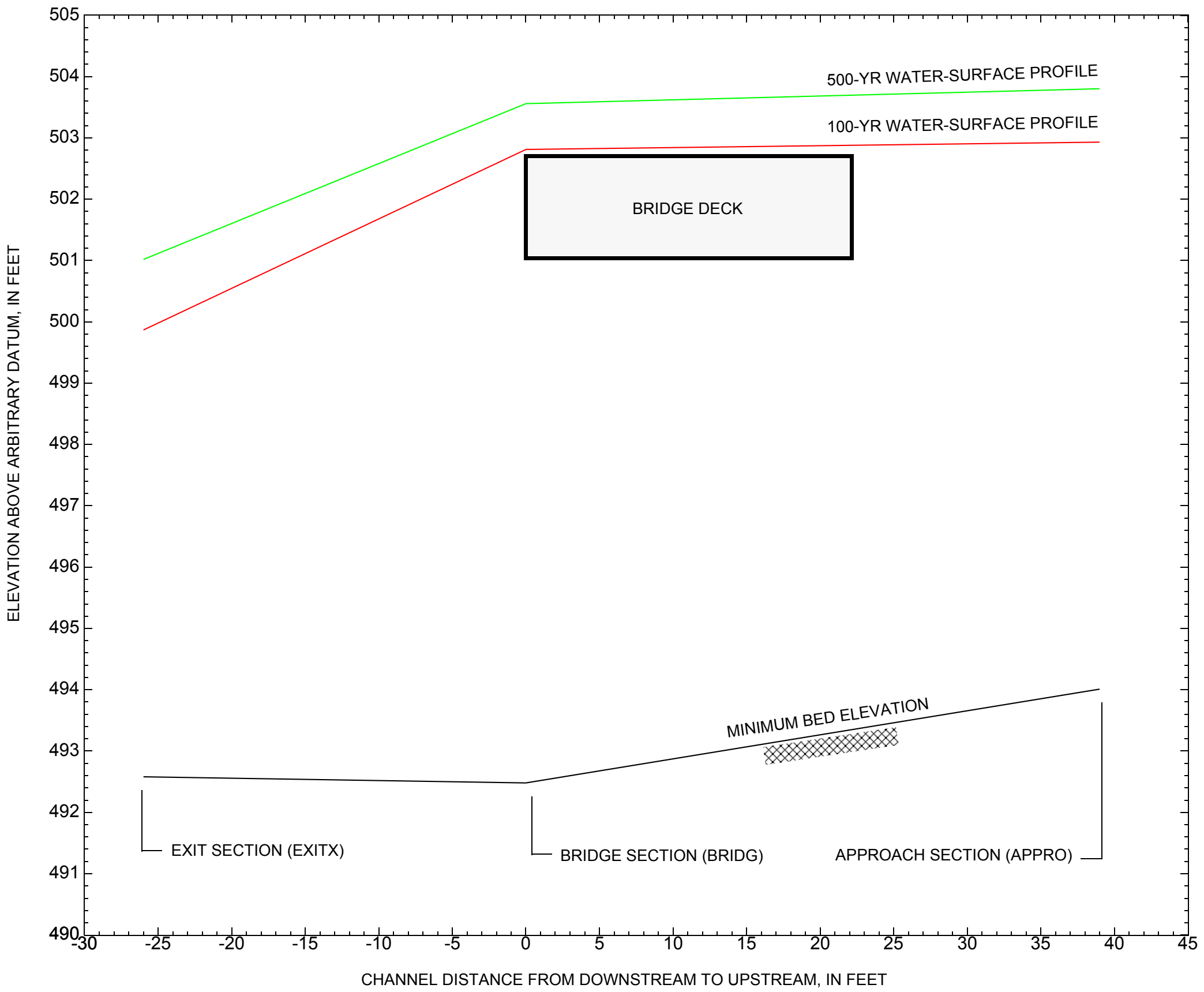

Figure 7. Water-surface profiles for the 100- and 500-year discharges at structure MAIDTH00070004 on Town Highway 7, crossing Cutler Mill Brook, Maidstone, Vermont. 


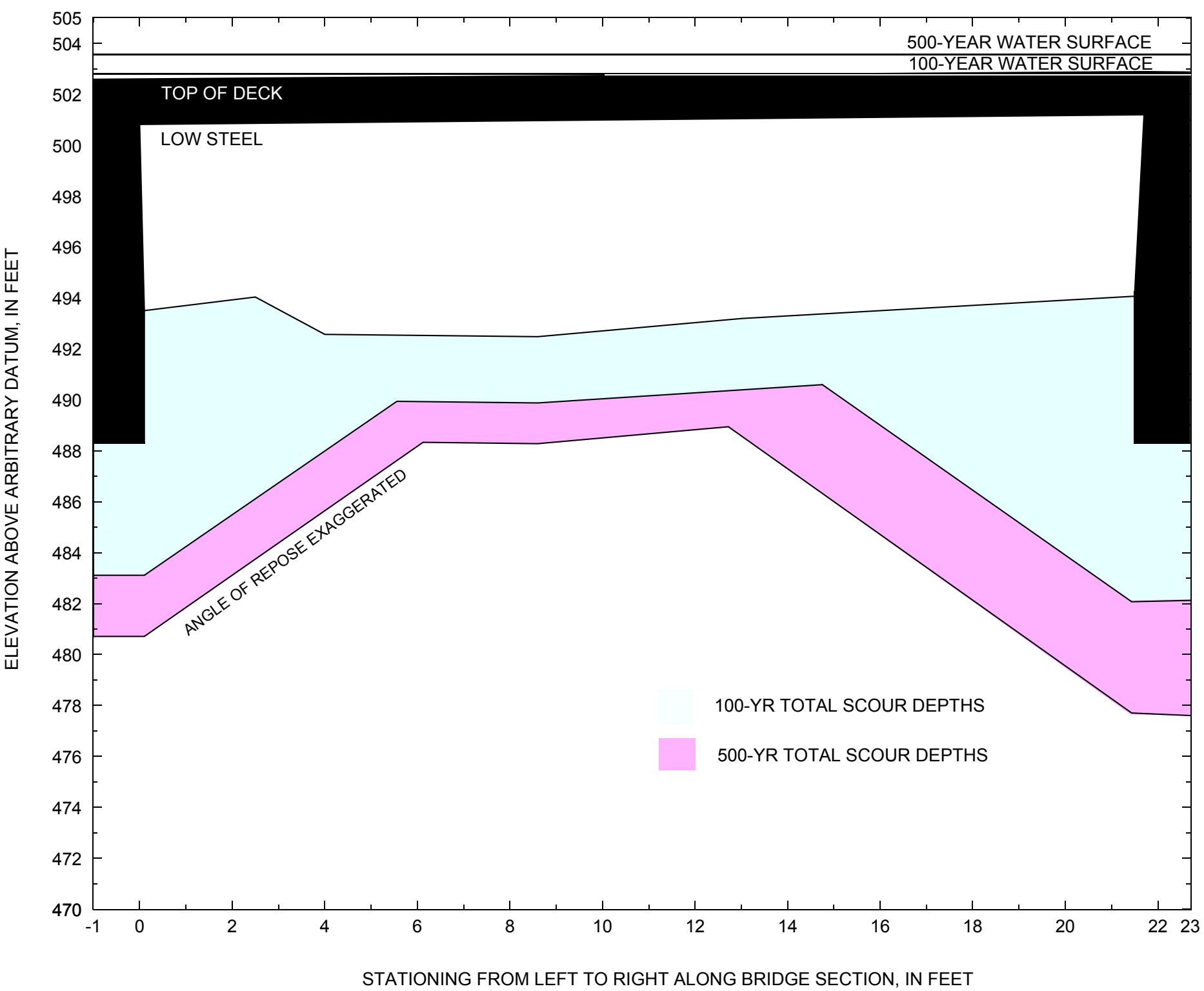

Figure 8. Scour elevations for the 100-year and 500-year discharges at structure MAIDTH00070004 on Town Highway 7, crossing Cutler Mill Brook, Maidstone, Vermont. 
Table 1. Remaining footing/pile depth at abutments for the 100-year discharge at structure MAIDTH00070004 on Town Highway 7, crossing Cutler Mill Brook, Maidstone, Vermont.

[VTAOT, Vermont Agency of Transportation; --,no data]

\begin{tabular}{|c|c|c|c|c|c|c|c|c|c|c|c|}
\hline Description & Station $^{1}$ & $\begin{array}{l}\text { VTAOT } \\
\text { minimum } \\
\text { low-chord } \\
\text { elevation } \\
\text { (feet) }\end{array}$ & $\begin{array}{l}\text { Surveyed } \\
\text { minimum } \\
\text { low-chord } \\
\text { elevation } \\
\text { (feet) }\end{array}$ & $\begin{array}{c}\text { Bottom of } \\
\text { footing/pile } \\
\text { elevation }{ }^{2} \\
\text { (feet) }\end{array}$ & $\begin{array}{c}\text { Channel } \\
\text { elevation at } \\
\text { abutment/ } \\
\text { pier }^{2} \\
\text { (feet) }\end{array}$ & $\begin{array}{l}\text { Contraction } \\
\text { scour depth } \\
\text { (feet) }\end{array}$ & $\begin{array}{l}\text { Abutment } \\
\text { scour } \\
\text { depth } \\
\text { (feet) }\end{array}$ & $\begin{array}{l}\text { Pier } \\
\text { scour } \\
\text { depth } \\
\text { (feet) }\end{array}$ & $\begin{array}{l}\text { Depth of } \\
\text { total scour } \\
\text { (feet) }\end{array}$ & $\begin{array}{c}\text { Elevation of } \\
\text { scour }^{2} \\
\text { (feet) }\end{array}$ & $\begin{array}{c}\text { Remaining } \\
\text { footing/pile } \\
\text { depth } \\
\text { (feet) }\end{array}$ \\
\hline \multicolumn{12}{|c|}{100 -yr. discharge is 1,800 cubic-feet per second } \\
\hline Left abutment & 0.0 & 500.8 & 500.8 & 488.3 & 493.5 & 2.6 & 7.8 & -- & 10.4 & 483.1 & -5.2 \\
\hline Right abutment & 21.7 & 501.2 & 501.2 & 488.3 & 494.3 & 2.6 & 9.5 & -- & 12.1 & 482.2 & -6.1 \\
\hline
\end{tabular}

1.Measured along the face of the most constricting side of the bridge.

2.Arbitrary datum for this study.

Table 2. Remaining footing/pile depth at abutments for the 500-year discharge at structure MAIDTH00070004 on Town Highway 7, crossing Cutler Mill Brook, Maidstone, Vermont.

[VTAOT, Vermont Agency of Transportation; --, no data]

\begin{tabular}{|c|c|c|c|c|c|c|c|c|c|c|c|}
\hline Description & Station ${ }^{1}$ & $\begin{array}{l}\text { VTAOT } \\
\text { minimum } \\
\text { low-chord } \\
\text { elevation } \\
\text { (feet) }\end{array}$ & $\begin{array}{l}\text { Surveyed } \\
\text { minimum } \\
\text { low-chord } \\
\text { elevation } \\
\text { (feet) }\end{array}$ & $\begin{array}{c}\text { Bottom of } \\
\text { footing/pile } \\
\text { elevation }{ }^{2} \\
\text { (feet) }\end{array}$ & $\begin{array}{c}\text { Channel } \\
\text { elevation at } \\
\text { abutment/ } \\
\text { pier }^{2} \\
\text { (feet) }\end{array}$ & $\begin{array}{c}\text { Contraction } \\
\text { scour depth } \\
\text { (feet) }\end{array}$ & $\begin{array}{l}\text { Abutment } \\
\text { scour } \\
\text { depth } \\
\text { (feet) }\end{array}$ & $\begin{array}{l}\text { Pier } \\
\text { scour } \\
\text { depth } \\
\text { (feet) }\end{array}$ & $\begin{array}{l}\text { Depth of } \\
\text { total scour } \\
\text { (feet) }\end{array}$ & $\begin{array}{c}\text { Elevation of } \\
\text { scour }^{2} \\
\text { (feet) }\end{array}$ & $\begin{array}{c}\text { Remaining } \\
\text { footing/pile } \\
\text { depth } \\
\text { (feet) }\end{array}$ \\
\hline \multicolumn{12}{|c|}{500 -yr. discharge is 3,090 cubic-feet per second } \\
\hline Left abutment & 0.0 & 500.8 & 500.8 & 488.3 & 493.5 & 4.2 & 8.6 & -- & 12.8 & 480.7 & -7.6 \\
\hline Right abutment & 21.7 & 501.2 & 501.2 & 488.3 & 494.3 & 4.2 & 12.4 & -- & 16.6 & 477.7 & -10.6 \\
\hline
\end{tabular}

1.Measured along the face of the most constricting side of the bridge.

2.Arbitrary datum for this study. 


\section{SELECTED REFERENCES}

Arcement, G.J., Jr., and Schneider, V.R., 1989, Guide for selecting Manning's roughness coefficients for natural channels and flood plains: U.S. Geological Survey Water-Supply Paper 2339, 38 p.

Barnes, H.H., Jr., 1967, Roughness characteristics of natural channels: U.S. Geological Survey Water-Supply Paper 1849,213 p.

Benson, M. A., 1962, Factors Influencing the Occurrence of Floods in a Humid Region of Diverse Terrain: U.S. Geological Survey WaterSupply Paper 1580-B, 64 p.

Brown, S.A. and Clyde, E.S., 1989, Design of riprap revetment: Federal Highway Administration Hydraulic Engineering Circular No. 11, Publication FHWA-IP-89-016, 156 p.

Federal Highway Administration, 1983, Runoff estimates for small watersheds and development of sound design: Federal Highway Administration Report FHWA-RD-77-158.

Federal Highway Administration, 1993, Stream Stability and Scour at Highway Bridges: Participant Workbook: Federal Highway Administration Report FHWA-HI-91-011.

Froehlich, D.C., 1989, Local scour at bridge abutments in Ports, M.A., ed., Hydraulic Engineering--Proceedings of the 1989 National Conference on Hydraulic Engineering: New York, American Society of Civil Engineers, p. 13-18.

Hayes, D.C.,1993, Site selection and collection of bridge-scour data in Delaware, Maryland, and Virginia: U.S. Geological Survey WaterResources Investigation Report 93-4017, 23 p.

Interagency Advisory Committee on Water Data, 1982, Guidelines for determining flood flow frequency: U.S. Geological Survey, Bulletin 17B of the Hydrology Subcommittee, 190 p.

Johnson, C.G. and Tasker, G.D.,1974, Progress report on flood magnitude and frequency of Vermont streams: U.S. Geological Survey OpenFile Report 74-130, 37 p.

Lagasse, P.F., Schall, J.D., Johnson, F., Richardson, E.V., Chang, F., 1995, Stream Stability at Highway Structures: Federal Highway Administration Hydraulic Engineering Circular No. 20, Publication FHWA-IP-90-014, 144 p.

Laursen, E.M., 1960, Scour at bridge crossings: Journal of the Hydraulics Division, American Society of Civil Engineers, v. 86, no. HY2, p. 39-53.

Potter, W. D., 1957a, Peak rates of runoff in the Adirondack, White Mountains, and Maine woods area, Bureau of Public Roads

Potter, W. D., 1957b, Peak rates of runoff in the New England Hill and Lowland area, Bureau of Public Roads

Richardson, E.V. and Davis, S.R., 1995, Evaluating scour at bridges: Federal Highway Administration Hydraulic Engineering Circular No. 18, Publication FHWA-IP-90-017, 204 p.

Richardson, E.V., Simons, D.B., and Julien, P.Y., 1990, Highways in the river environment: Federal Highway Administration Publication FHWA-HI-90-016.

Ritter, D.F., 1984, Process Geomorphology: W.C. Brown Co., Debuque, Iowa, 603 p.

Shearman, J.O., 1990, User's manual for WSPRO--a computer model for water surface profile computations: Federal Highway Administration Publication FHWA-IP-89-027, 187 p.

Shearman, J.O., Kirby, W.H., Schneider, V.R., and Flippo, H.N., 1986, Bridge waterways analysis model; research report: Federal Highway Administration Publication FHWA-RD-86-108, 112 p.

Talbot, A.N., 1887, The determination of water-way for bridges and culverts.

U.S. Department of Transportation, 1993, Stream stability and scour at highway bridges, Participant Workbook: Federal Highway Administration Publication FHWA HI-91-011.

U.S. Geological Survey, 1988, Groveton, Vermont 7.5 Minute Series quadrangle map: U.S. Geological Survey Topographic Maps, Scale 1:24,000. 


\section{APPENDIX A: \\ WSPRO INPUT FILE}




\section{WSPRO INPUT FILE}

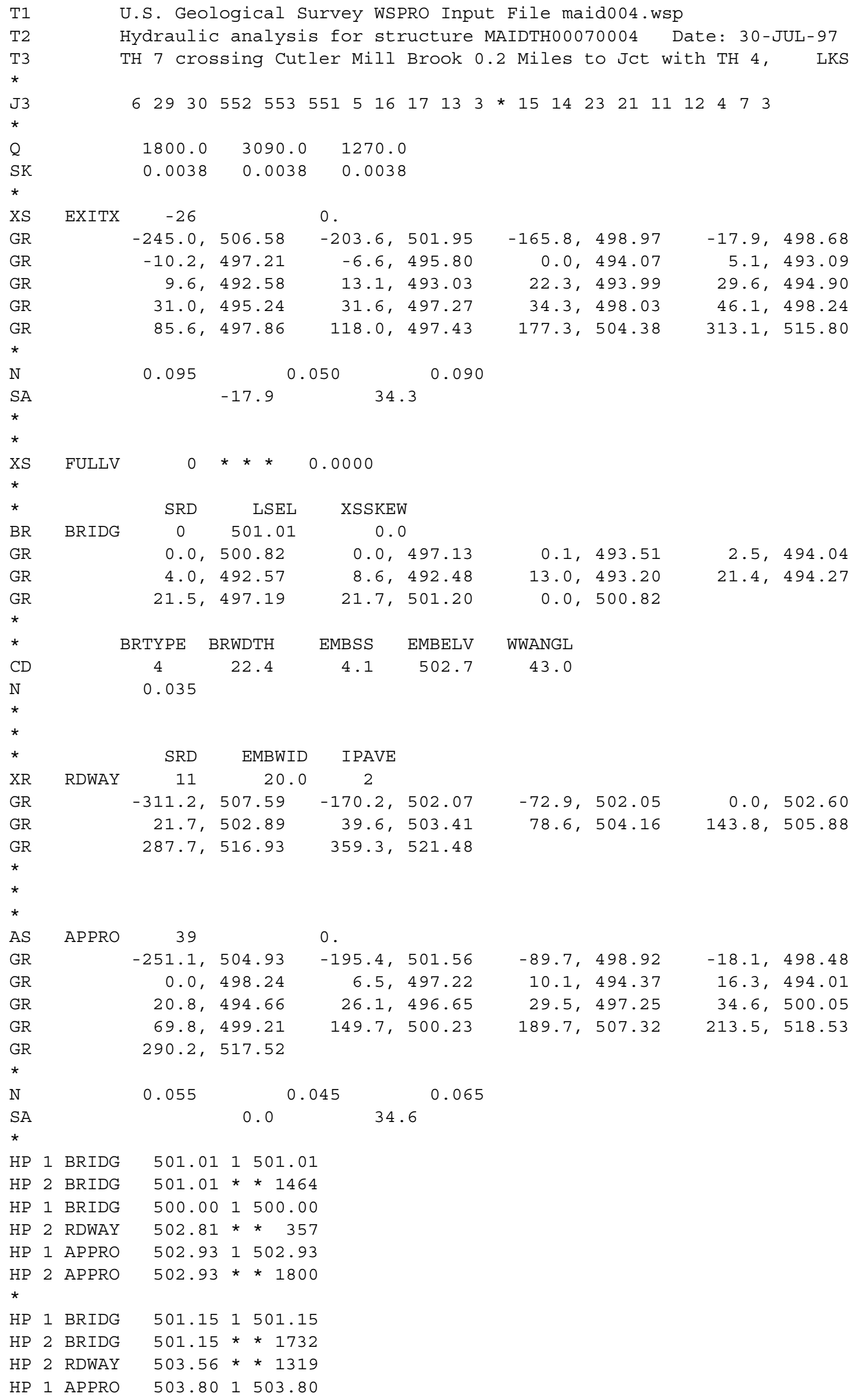




\section{APPENDIX B: \\ WSPRO OUTPUT FILE}


U.S. Geological Survey WSPRO Input File maido04.wsp

Hydraulic analysis for structure MAIDTH00070004 Date: 30-JUL-97

TH 7 crossing Cutler Mill Brook 0.2 Miles to Jct with TH 4, LKS *** RUN DATE \& TIME: 07-30-97 12:49

VELOCITY DISTRIBUTION: ISEQ $=3 ; \quad$ SECID $=$ BRIDG; $\quad$ SRD $=0$

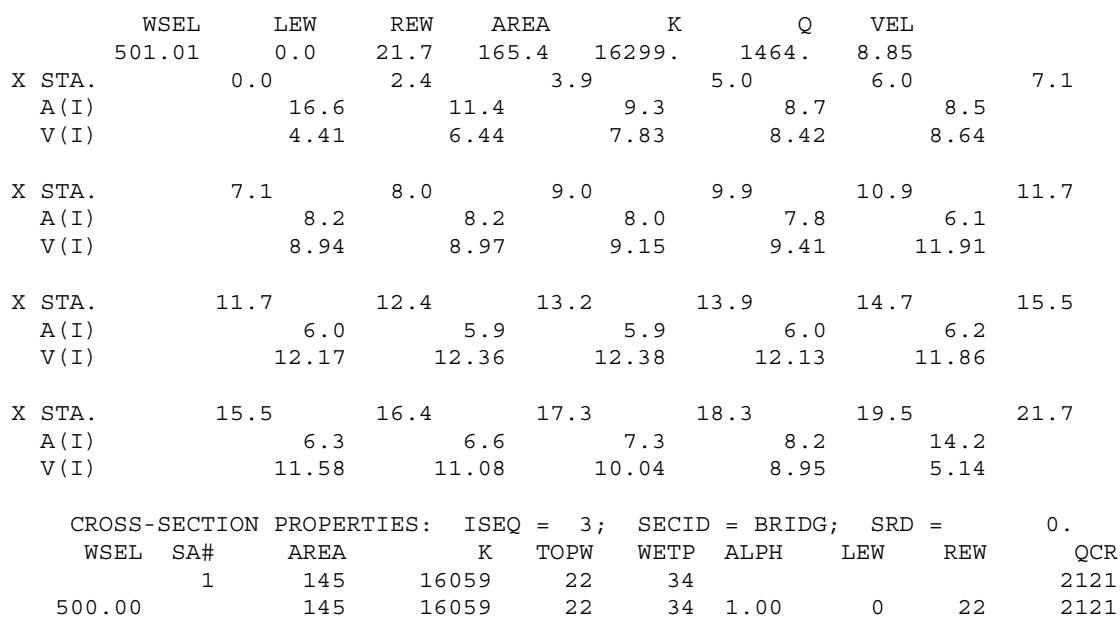

VELOCITY DISTRIBUTION: ISEQ $=4 ; \operatorname{SECID~}=$ RDWAY $; \quad \operatorname{SRD}=11$.

\begin{tabular}{|c|c|c|c|c|c|c|c|c|c|c|c|}
\hline & & WSEL & LEW & REW & & REA & $\mathrm{K}$ & $Q$ & VEL & & \\
\hline & 50 & $2.81-18$ & 39.1 & 15.7 & 117 & 7.0 & 1358. & 357 & 3.05 & & \\
\hline $\mathrm{X}$ & STA. & -189.1 & & -168.7 & & -160.7 & -15 & 3.3 & -145.9 & & -138.8 \\
\hline & $A(I)$ & & 8.1 & & 5.9 & & 5.5 & 5.5 & & 5.3 & \\
\hline & $V(I)$ & & 2.19 & & 3.04 & & 3.25 & 3.23 & & 3.34 & \\
\hline $\mathrm{X}$ & STA. & -138.8 & & -131.5 & & -124.5 & -11 & 7.4 & -110.3 & & 103.3 \\
\hline & $A(I)$ & & 5.4 & & 5.3 & & 5.3 & 5.3 & & 5.3 & \\
\hline & $V(I)$ & & 3.32 & & 3.38 & & 3.34 & 3.38 & & 3.37 & \\
\hline $\mathrm{X}$ & STA. & -103.3 & & -96.3 & & -89.3 & -82 & 2.2 & -75.2 & & -67.8 \\
\hline & $A(I)$ & & 5.3 & & 5.3 & & 5.4 & 5.3 & & 5.5 & \\
\hline & $V(I)$ & & 3.38 & & 3.37 & & 3.33 & 3.35 & & 3.26 & \\
\hline $\mathrm{X}$ & STA. & -67.8 & & -59.7 & & -49.6 & -37 & 7.2 & -18.7 & & 15.7 \\
\hline & $A(I)$ & & 5.7 & & 6.3 & & 6.7 & 7.8 & & 6.9 & \\
\hline & $V(I)$ & & 3.16 & & 2.85 & & 2.68 & 2.29 & & 2.59 & \\
\hline & CROSS- & -SECTION & PROPER & RTIES: & ISEQ & $=5 ;$ & SECID & $=\mathrm{APPRO} ;$ & ; $\quad$ SRD & $=$ & 39. \\
\hline & WSEL & SA\# & AREA & & $\mathrm{K}$ & TOPW & WETP & ALPH & LEW & REW & QCR \\
\hline & & 1 & 685 & & 9838 & 218 & 218 & & & & 6896 \\
\hline & & 2 & 233 & & 6388 & 35 & 37 & & & & 3433 \\
\hline & & 3 & 393 & & 8795 & 130 & 131 & & & & 3875 \\
\hline & 502.93 & & 1312 & & 5021 & 383 & 386 & 1.44 & -217 & 165 & 11463 \\
\hline
\end{tabular}

VELOCITY DISTRIBUTION: ISEQ $=5 ; \operatorname{SECID~}=$ APPRO; $\quad$ SRD $=39$.

$\begin{array}{rrrrrrr}\text { WSEL } & \text { LEW } & \text { REW } & \text { AREA } & \text { K } & \text { Q } & \text { VEL } \\ 502.93 & -218.0 & 164.9 & 1311.7 & 85021 . & 1800 . & 1.37\end{array}$

\begin{tabular}{|c|c|c|c|c|c|c|c|c|c|c|}
\hline \multirow[t]{3}{*}{$\mathrm{x}$} & STA. & -218.0 & -144.7 & & -115.4 & & -94.6 & & -77.4 & \multirow[t]{3}{*}{-61.3} \\
\hline & $A(I)$ & 117.0 & & 88.0 & & 75.3 & & 69.1 & & \\
\hline & $V(I)$ & 0.77 & & 1.02 & & 1.19 & & 1.30 & & \\
\hline \multirow[t]{3}{*}{$\mathrm{X}$} & STA. & $-61 \cdot 3$ & -46.1 & & -31.6 & & -17.7 & & -4.7 & 5.4 \\
\hline & $A(I)$ & 63.9 & & 62.7 & & 61.3 & & 59.2 & & \\
\hline & $V(I)$ & 1.41 & & 1.44 & & 1.47 & & 1.52 & & \\
\hline \multirow[t]{3}{*}{$\mathrm{x}$} & STA. & 5.4 & 11.0 & & 14.6 & & 18.2 & & 22.2 & 28.1 \\
\hline & $A(I)$ & 39.1 & & 32.0 & & 31.8 & & 33.2 & & \\
\hline & $V(I)$ & 2.30 & & 2.81 & & 2.83 & & 2.71 & & \\
\hline \multirow[t]{3}{*}{$\mathrm{x}$} & STA. & 28.1 & 47.2 & & 70.6 & & 93.2 & & 120.1 & 164.9 \\
\hline & $A(I)$ & 68.1 & & 81.0 & & 80.7 & & 87.3 & & \\
\hline & $V(I)$ & 1.32 & & 1.11 & & 1.12 & & 1.03 & & \\
\hline
\end{tabular}


WSPRO OUTPUT FILE (continued)

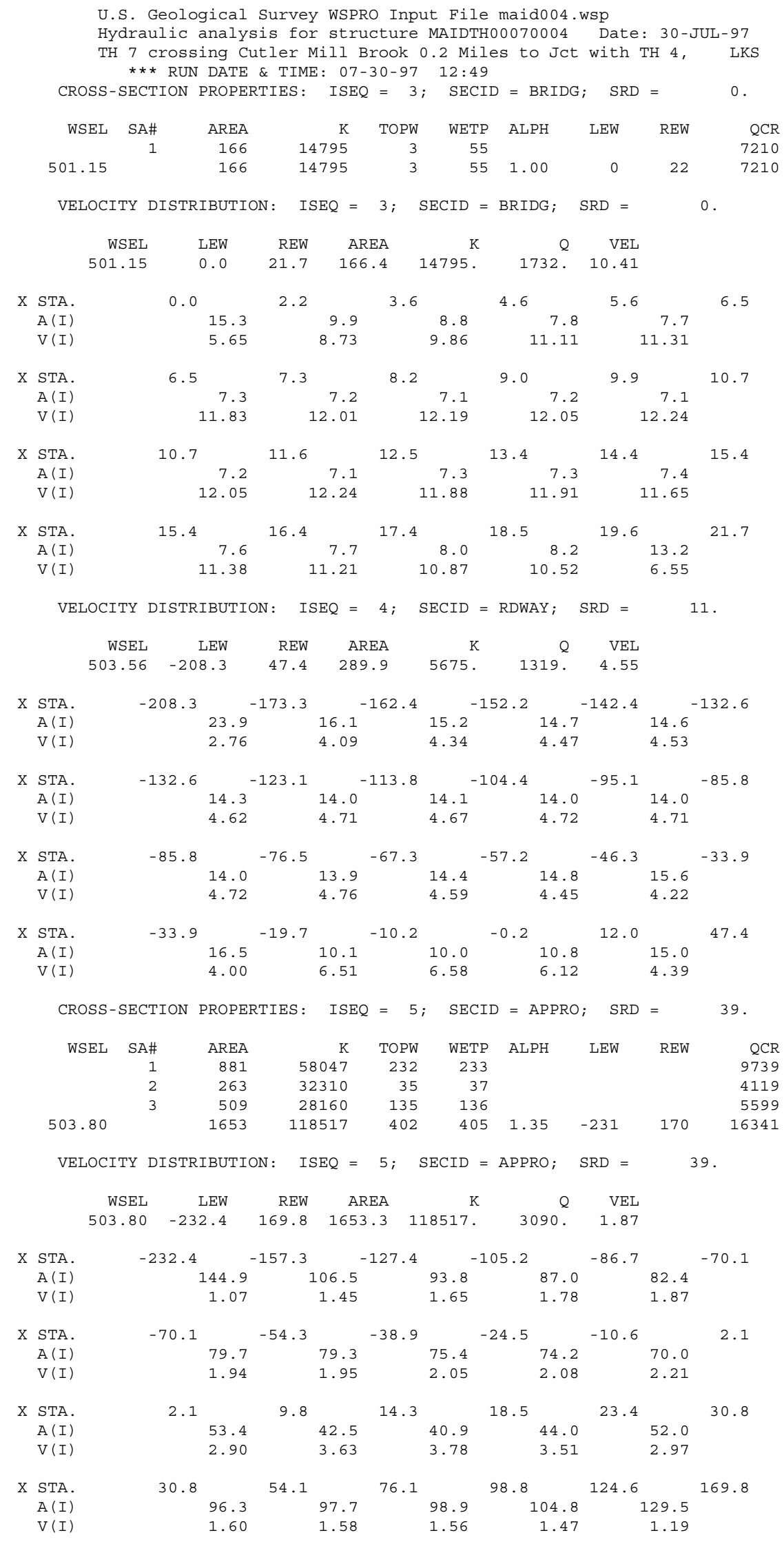


WSPRO OUTPUT FILE (continued)

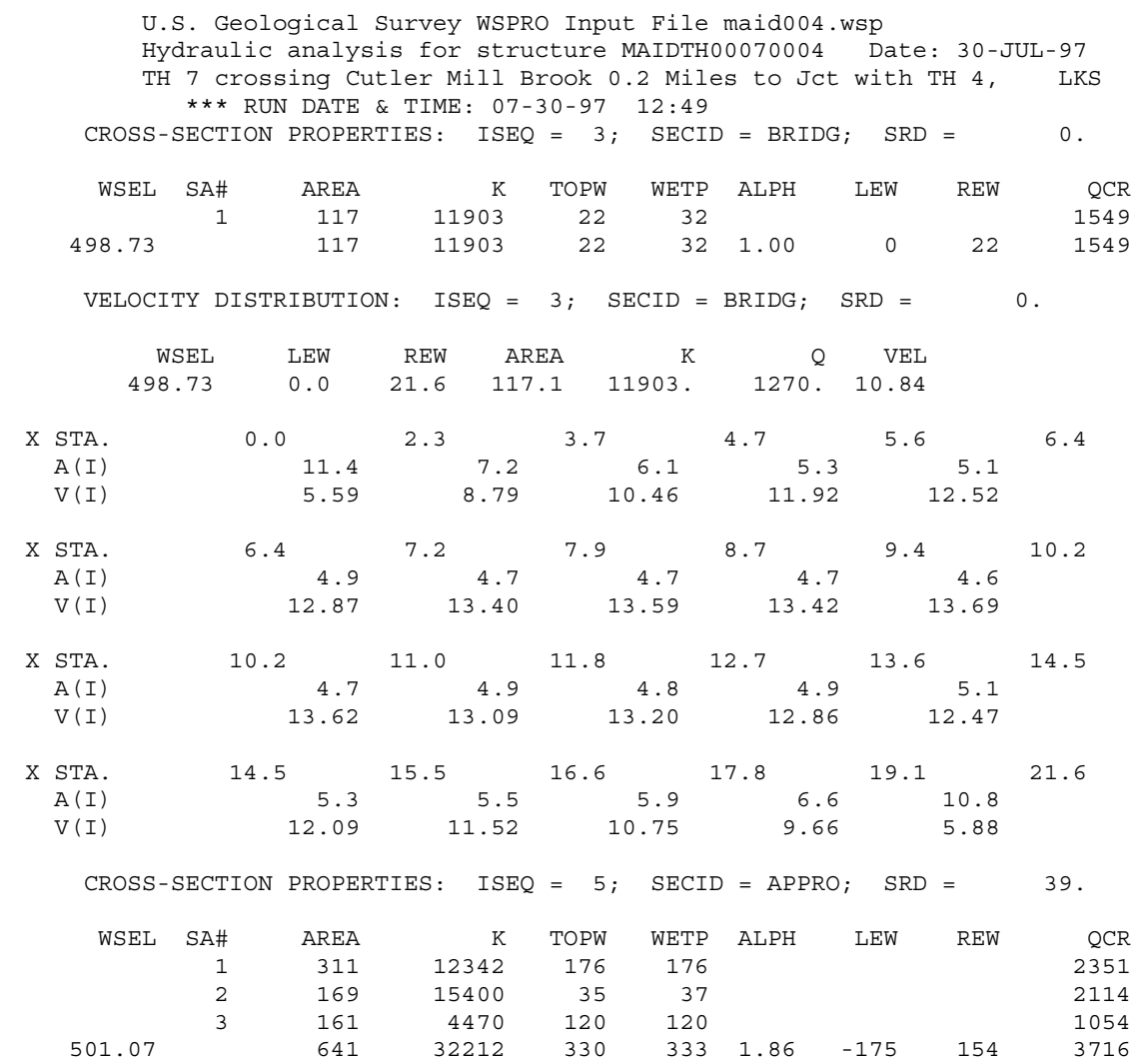

VELOCITY DISTRIBUTION: ISEQ $=5 ;$ SECID $=$ APPRO; $\operatorname{SRD}=39$.

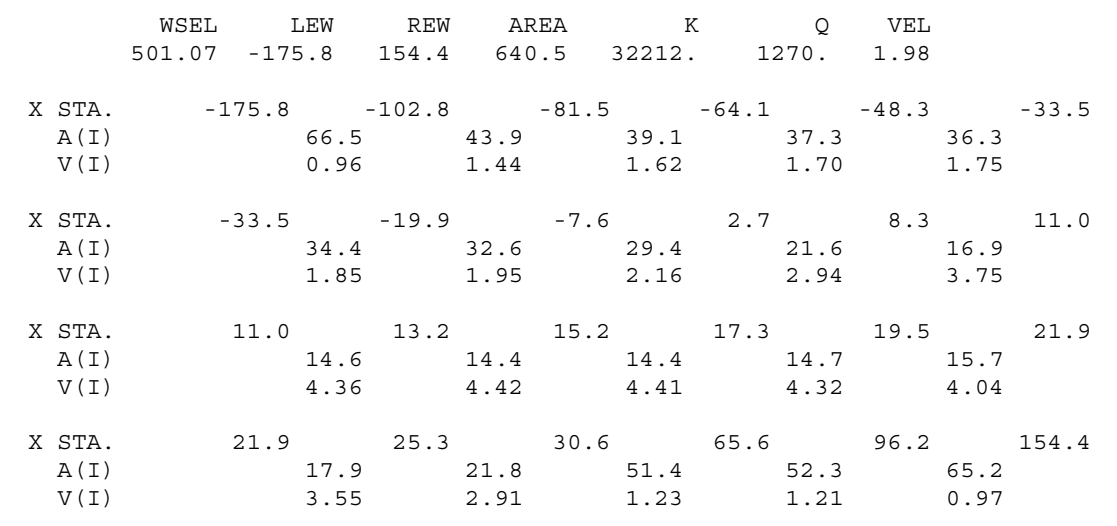


WSPRO OUTPUT FILE (continued)

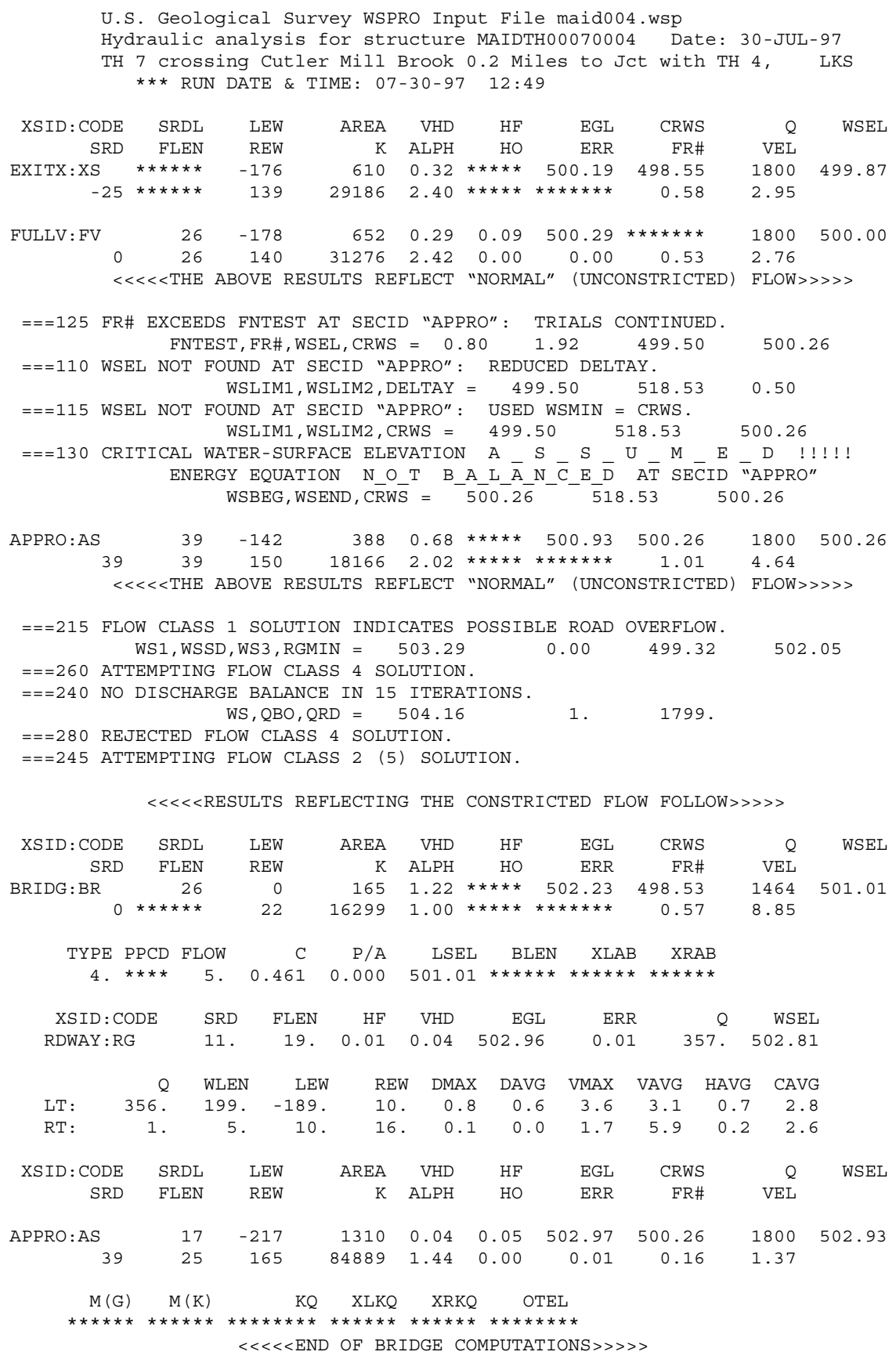

FIRST USER DEFINED TABLE.

$\begin{array}{lrrrrrrrr}\text { XSID : CODE } & \text { SRD } & \text { LEW } & \text { REW } & Q & \text { K } & \text { AREA } & \text { VEL } & \text { WSEL } \\ \text { EXITX : XS } & -26 . & -177 . & 139 . & 1800 . & 29186 . & 610 . & 2.95 & 499.87 \\ \text { FULLV : FV } & 0 . & -179 . & 140 . & 1800 . & 31276 . & 652 . & 2.76 & 500.00 \\ \text { BRIDG : BR } & 0 . & 0 . & 22 . & 1464 . & 16299 . & 165 . & 8.85 & 501.01 \\ \text { RDWAY : RG } & 11 . * * * * * * * & 356 . & 357 . * * * * * * * * & 0 . & 2.00 & 502.81 \\ \text { APPRO : AS } & 39 . & -218 . & 165 . & 1800 . & 84889 . & 1310 . & 1.37 & 502.93\end{array}$

SECOND USER DEFINED TABLE.

$\begin{array}{lcrrrrrrrr}\text { XSID : CODE } & \text { CRWS } & \text { FR\# } & \text { YMIN } & \text { YMAX } & \text { HF } & \text { HO } & \text { VHD } & \text { EGL } & \text { WSEL } \\ \text { EXITX:XS } & 498.55 & 0.58 & 492.58 & 515.80 * * * * * * * * * * & 0.32 & 500.19 & 499.87 \\ \text { FULLV:FV } & * * * * * * * * & 0.53 & 492.58 & 515.80 & 0.09 & 0.00 & 0.29 & 500.29 & 500.00 \\ \text { BRIDG : BR } & 498.53 & 0.57 & 492.48 & 501.20 * * * * * * * * * * & 1.22 & 502.23 & 501.01 \\ \text { RDWAY:RG } & * * * * * * * * * * * * * * * & 502.05 & 521.48 & 0.01 * * * * * * & 0.04 & 502.96 & 502.81 \\ \text { APPRO:AS } & 500.26 & 0.16 & 494.01 & 518.53 & 0.05 & 0.00 & 0.04 & 502.97 & 502.93\end{array}$


WSPRO OUTPUT FILE (continued)

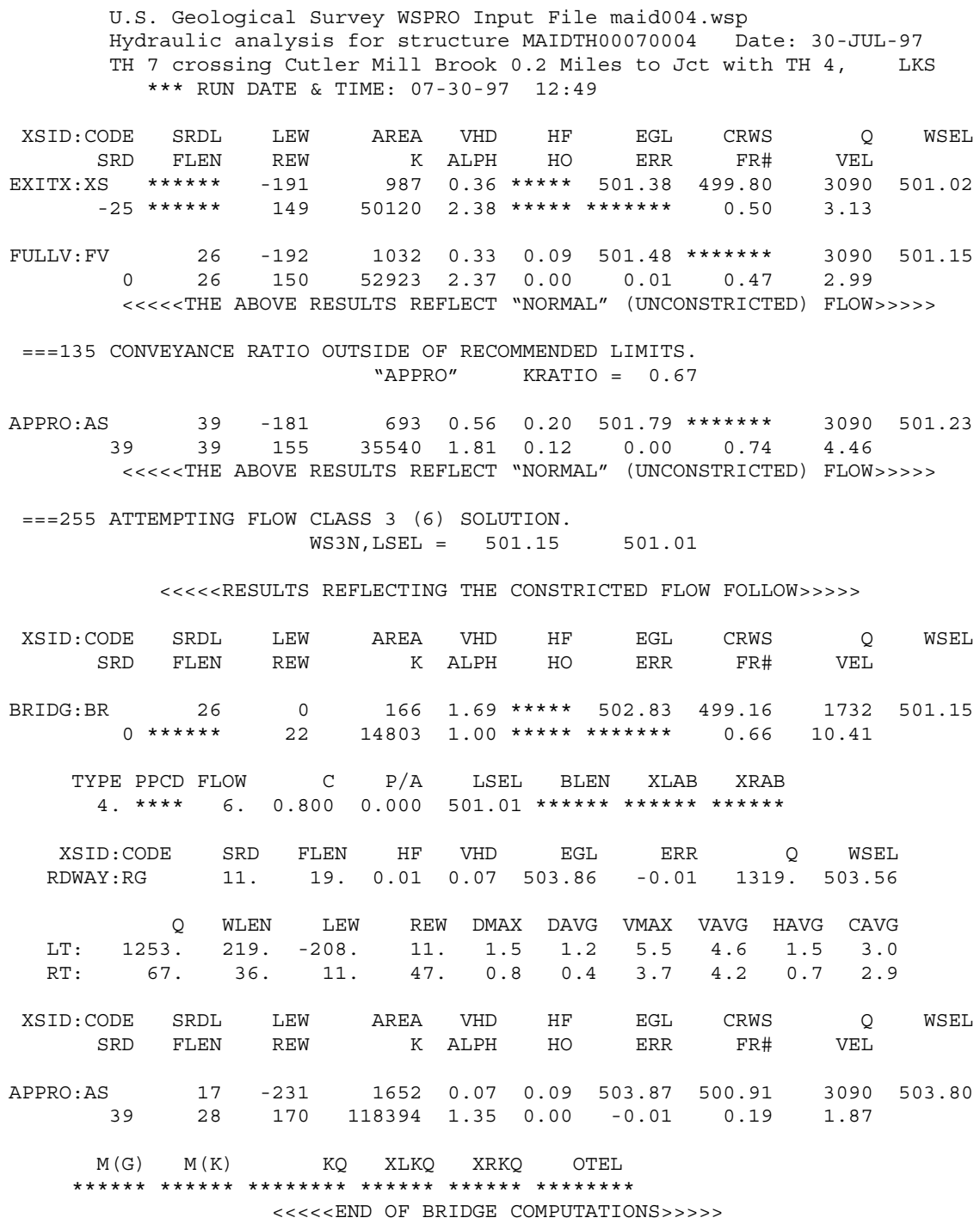

FIRST USER DEFINED TABLE.

\begin{tabular}{|c|c|c|c|c|c|c|c|c|}
\hline XSID : CODE & SRD & LEW & REW & 0 & $\mathrm{~K}$ & AREA & VEL & WSEL \\
\hline EXITX:XS & -26 & -192. & 149. & 3090. & 50120. & 987. & 3.13 & 501.02 \\
\hline FULLV : FV & 0 . & -193. & 150. & 3090. & 52923. & 1032. & 2.99 & 501.15 \\
\hline BRIDG : BR & 0 . & 0 . & 22 . & 1732. & 14803. & 166 & 10.41 & 501.15 \\
\hline RDWAY : RG & 11 * & $* * * * *$ & 1253. & 1319. & $\star \star \star \star \star * \star * \star *$ & $\star \star \star \star \star \star *$ & 2.00 & 503.56 \\
\hline APPRO : AS & 39. & -232 . & 170 . & 3090. & 118394. & 1652 . & 1.87 & 503.80 \\
\hline
\end{tabular}

SECOND USER DEFINED TABLE.

$\begin{array}{lrrrrrrrrr}\text { XSID:CODE } & \text { CRWS } & \text { FR\# } & \text { YMIN } & \text { YMAX } & \text { HF } & \text { HO } & \text { VHD } & \text { EGL } & \text { WSEL } \\ \text { EXITX:XS } & 499.80 & 0.50 & 492.58 & 515.80 * * * * * * * * * * & 0.36 & 501.38 & 501.02 \\ \text { FULLV:FV } & * * * * * * * * & 0.47 & 492.58 & 515.80 & 0.09 & 0.00 & 0.33 & 501.48 & 501.15 \\ \text { BRIDG:BR } & 499.16 & 0.66 & 492.48 & 501.20 * * * * * * * * * * * & 1.69 & 502.83 & 501.15 \\ \text { RDWAY:RG } & * * * * * * * * * * * * * * * * & 502.05 & 521.48 & 0.01 * * * * * * & 0.07 & 503.86 & 503.56 \\ \text { APPRO:AS } & 500.91 & 0.19 & 494.01 & 518.53 & 0.09 & 0.00 & 0.07 & 503.87 & 503.80\end{array}$


WSPRO OUTPUT FILE (continued)

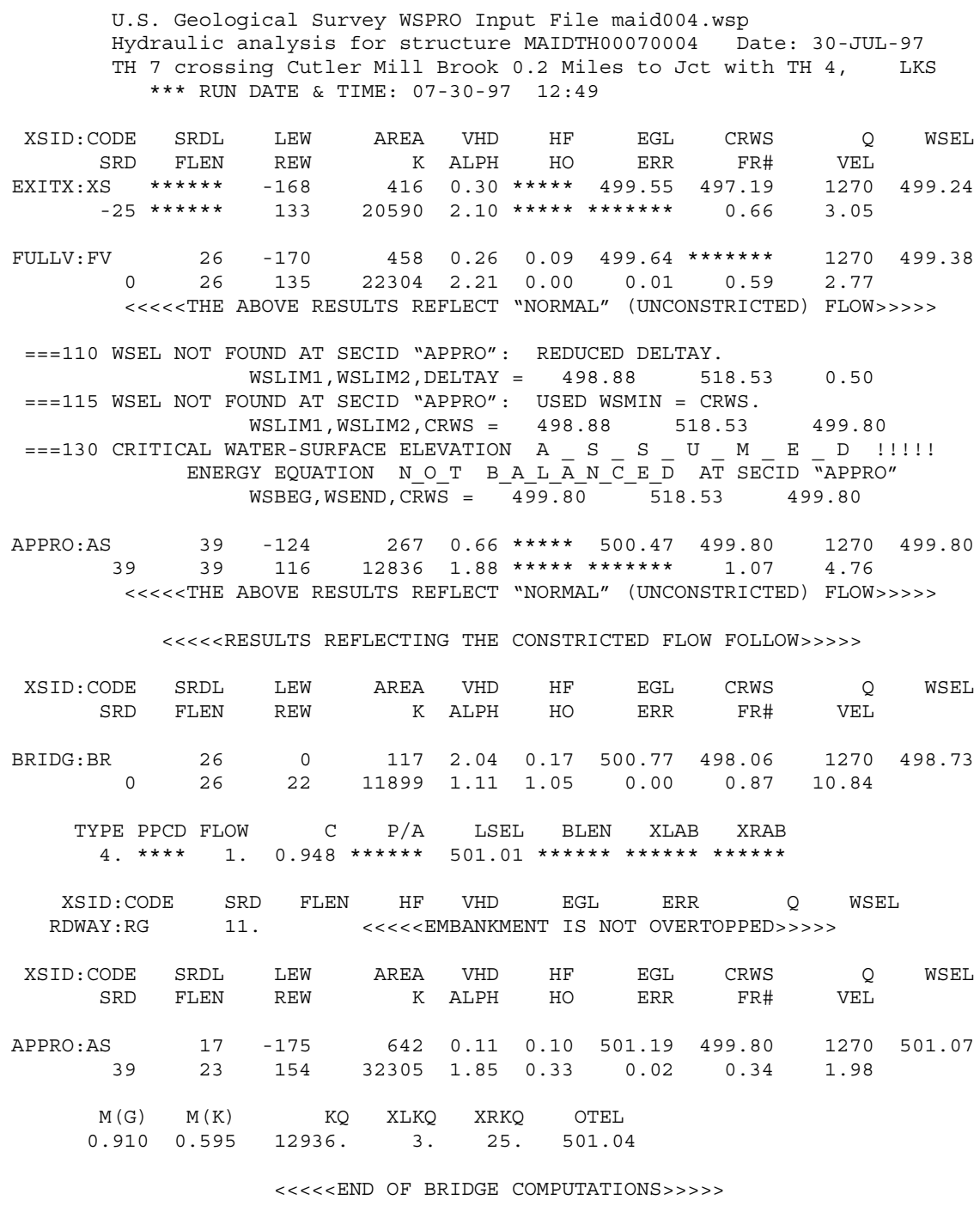

FIRST USER DEFINED TABLE.

\begin{tabular}{|c|c|c|c|c|c|c|c|c|}
\hline XSID : CODE & SRD & LEW & REW & $\mathrm{Q}$ & $\mathrm{K}$ & AREA & VEL & WSEL \\
\hline EXITX:XS & -26 & -169. & 133. & 1270. & 20590 . & 416 & 3.05 & 499.24 \\
\hline FULLV : FV & 0. & -171. & 135. & 1270 . & 22304 . & 458. & 2.77 & 499.38 \\
\hline BRIDG : BR & 0 & 0 & 22 & 1270. & 11899. & 117. & 10.84 & 498.73 \\
\hline RDWAY : RG & \multicolumn{3}{|c|}{$11 . * * * * * * * * * * * * * *$} & \multicolumn{3}{|c|}{$0 . * * * * * * * * * * * * * * * * * * *$} & \multirow{2}{*}{\multicolumn{2}{|c|}{$\begin{array}{l}2.00 * * * * * * * * \\
1.98 \quad 501.07\end{array}$}} \\
\hline APPRO:AS & 39. & -176 & 154. & 1270. & 32305 . & 642. & & \\
\hline
\end{tabular}

SECOND USER DEFINED TABLE.

\begin{tabular}{|c|c|c|c|c|c|c|c|c|c|}
\hline XSID : CODE & CRWS & FR\# & YMIN & YMAX & $\mathrm{HF}$ & $\mathrm{HO}$ & VHD & EGL & WSEL \\
\hline EXITX:XS & 497.19 & 0.66 & 492.58 & $515.80 x$ & 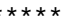 & $\star * \star *$ & 0.30 & 499.55 & 499.24 \\
\hline FULLV : FV & $\star \star \star \star * \star * \star *$ & 0.59 & 492.58 & 515.80 & 0.09 & 0.00 & 0.26 & 499.64 & 499.38 \\
\hline BRIDG : BR & 498.06 & 0.87 & 492.48 & 501.20 & 0.17 & 1.05 & 2.04 & 500.77 & 498.73 \\
\hline RDWAY : RG & 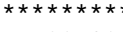 & $* * * * *$ & 502.05 & $521.48 *$ & $\star \star \star * *$ & & & 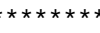 & $* * * *$ \\
\hline$\triangle P P R O: A S$ & 499.80 & 0.34 & 494.01 & 518.53 & 0.10 & 0.33 & 0.11 & 501.19 & 501.07 \\
\hline
\end{tabular}




\section{APPENDIX C:}

\section{BED-MATERIAL PARTICLE-SIZE DISTRIBUTION}




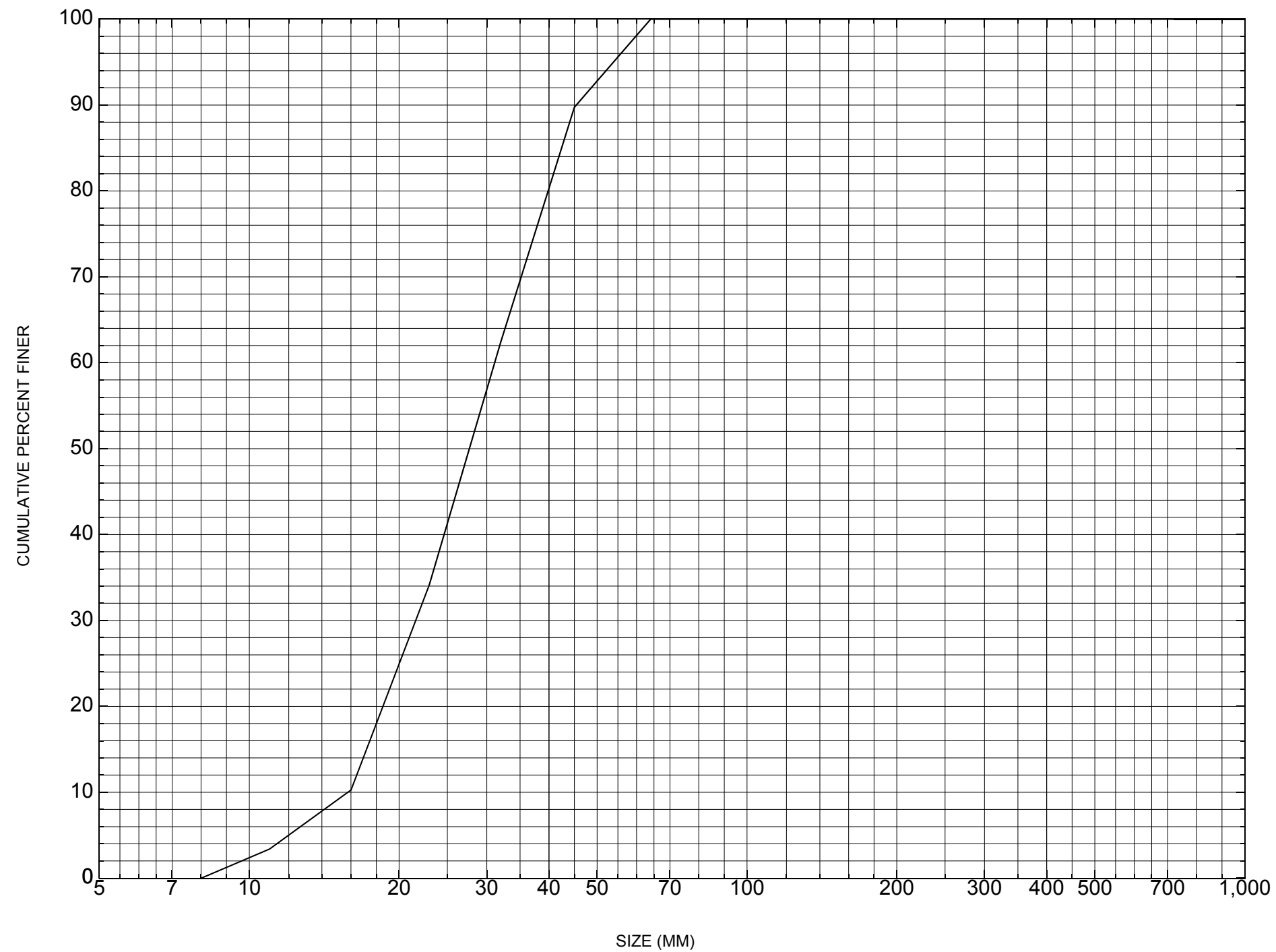

Appendix C. Bed material particle-size distribution for a pebble count in the channel approach of structure MAIDTH00070004, in Maidstone, Vermont. 


\section{APPENDIX D: \\ HISTORICAL DATA FORM}




\section{Structure Number MAIDTH00070004}

\section{General Location Descriptive}

Data collected by (First Initial, Full last name) $\mathbf{E}$. BOEHMLER

Date $(M M / D D / Y Y) \_\mathbf{0 8} / \underline{\mathbf{0 5}} / \underline{\mathbf{9 4}}$

Highway District Number (I - 2; nn) 07

Town (FIPS place code; I - 4; nnnnn) $\mathbf{4 2 4 7 5}$

Waterway (I - 6) CUTLER MILL BROOK

Route Number TH007

Topographic Map Groveton, NH

Latitude (I - 16; nnnn.n) $\mathbf{4 4 3 5 5}$
County (FIPS county code; I - 3; nnn)

Mile marker (I - 11; nnn.nnn) $\mathbf{0 0 0 0 0 0}$

Road Name (I - 7): -

Vicinity (I - 9) 0.2 MI JCT TH $7+$ TH 4

Hydrologic Unit Code: $\mathbf{0 1 0 8 0 1 0 1}$

Longitude (i - 17; nnnnn.n) 71357

\section{Select Federal Inventory Codes}

FHWA Structure Number (I - 8) $\mathbf{1 0 0 5 1 5 0 0 0 4 0 5 1 5}$

Maintenance responsibility $(I-21 ; n n) \_$03 $\quad$ Maximum span length $(I-48 ; n n n n) \underline{\mathbf{0 0 2 2}}$

Year built (I - 27; YYYY) 1975

Structure length (I - 49; nnnnnn) $\underline{\mathbf{0 0 0 0 2 5}}$

Average daily traffic, ADT (I - 29; nnnnnn) 000010 Deck Width (I-52; nn.n) 200

Year of ADT (I - 30; YY) $\mathbf{9 1}$

Channel \& Protection $(I-61 ; n) \underline{5}$

Opening skew to Roadway $(I-34 ; n n) \quad \mathbf{0 0}$

Waterway adequacy $(I-71 ; n) \quad 6$

Operational status $(I-41 ; X) \quad \mathbf{A}$

Underwater Inspection Frequency $(I-92 B ; X Y Y) \_\mathbf{N}$

Structure type (I - 43; nnn) 101

Year Reconstructed (I - 106) $\mathbf{0 0 0 0}$

Approach span structure type $(I-44 ; n n n) \quad \mathbf{0 0 0}$ Clear span $(n n n . n f t)$

Number of spans (I - 45; nnn) $\mathbf{0 0 1}$

Vertical clearance from streambed (nnn.n ft) $\underline{\mathbf{0 0 6 . 8}}$

Number of approach spans (I - 46; nnnn) $\mathbf{0 0 0 0}$

Waterway of full opening $\left(n n n . n \mathrm{ft}^{2}\right)$

Comments:

The structural inspection report of 9/1/92 indicates the structure is a concrete slab type bridge. Minor cracks are reported in both abutment walls with no apparent settlement. The footing is not exposed and there is no channel scour or embankment erosion noted. Further, point bars and debris accumulation are reported as minor. The deepest part of the channel is noted along the left abutment. Stone fill is reported as not present on the abutments. 


\section{Bridge Hydrologic Data}

Is there hydrologic data available? $\mathbf{N}$ if No, type ctrl-n $h \quad$ VTAOT Drainage area $\left(\mathrm{mi}^{2}\right): \mathbf{1 8 . 3}$

Terrain character:

Stream character \& type: _

Streambed material:

Discharge Data (cfs):

$$
\mathrm{Q}_{2.33} \frac{-}{\mathbf{1 4 0 0}}
$$

$\mathrm{Q}_{10} \frac{\mathbf{8 5 0}}{\mathbf{1 8 0 0}}$

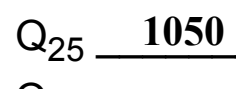

$Q_{500}$

Record flood date $(M M / D D / Y Y)$ :

Water surface elevation $(f t):-$

Estimated Discharge (cfs): _ _ Velocity at Q 25 (ft/s): $\underline{\mathbf{1 0 . 2}}$

Ice conditions (Heavy, Moderate, Light) : - _ Debris (Heavy, Moderate, Light): LIGHT

The stage increases to maximum highwater elevation (Rapidly, Not rapidly): -

The stream response is (Flashy, Not flashy):

Describe any significant site conditions upstream or downstream that may influence the stream's stage: -

Watershed storage area (in percent):

The watershed storage area is: - _ (1-mainly at the headwaters; 2- uniformly distributed; 3-immediatly upstream oi the site)

Water Surface Elevation Estimates for Existing Structure:

\begin{tabular}{|l|l|l|l|l|l|}
\hline Peak discharge frequency & $Q_{2.33}$ & $Q_{10}$ & $Q_{25}$ & $Q_{50}$ & $Q_{100}$ \\
Water surface elevation (ft)) & - & $\mathbf{5 . 5}$ & $\mathbf{6 . 5}$ & $\mathbf{8 . 1}$ & $\mathbf{8 . 9}$ \\
Velocity $(\mathrm{ft} / \mathrm{sec})$ & - & - & $\mathbf{1 0 . 2}$ & - & - \\
\hline
\end{tabular}

Long term stream bed changes: -

Is the roadway overtopped below the $\mathrm{Q}_{100}$ ? (Yes, No, Unknown): $\mathbf{U}$ Frequency: Relief Elevation $(f t)$ :

Discharge over roadway at $Q_{100}\left(f^{3} / \mathrm{sec}\right)$ :

Are there other structures nearby? (Yes, No, Unknown): $\mathbf{Y}$ Upstream distance (miles): $\mathbf{1 . 2}$ Town: If No or Unknown, type ctrl-n os Highway No. : $\mathbf{T H} 4$ Structure No. : 5 Year Built: 1968

Clear span $(f t)$ : Clear Height (ft): 6.6 Full Waterway $\left(f^{2}\right)$ : 
Upstream distance (miles):

Highway No. : TH 5

Town: Maidstone

Year Built:

1985

Clear span $(f t): \underline{\mathbf{2 0 . 8}}$

Clear Height (ft): $\mathbf{2 0 . 7}$

Structure No. : 6

Structure Type: 101

Comments:

\section{USGS Watershed Data}

Watershed Hydrographic Data

Drainage area $(D A) \stackrel{18.11}{\mathrm{mi}^{2}}$

Watershed storage (ST) 2.2

Bridge site elevation 870

Main channel length

11.55 $\mathrm{ft}$ $\%$

Lake/pond/swamp area

0.4 $m i^{2}$ $10 \%$ channel length elevation $\mathbf{9 8 0}$ $\mathrm{ft} \quad 85 \%$ channel length elevation $\mathrm{ft}$

Main channel slope $(S)$
(S)

85.43 $\mathrm{ft} / \mathrm{mi}$

\section{Watershed Precipitation Data}

Average site precipitation in

Average headwater precipitation in

Maximum 2yr-24hr precipitation event $(124,2)$ in

Average seasonal snowfall (Sn) $\mathrm{ft}$ 


\section{Bridge Plan Data}

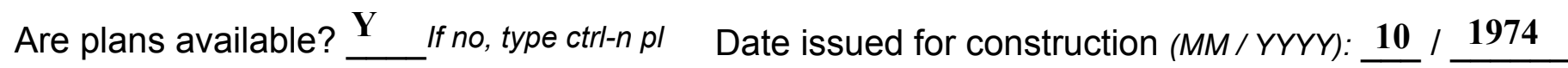
Project Number $\mathbf{T H} 3515$

Minimum channel bed elevation: 491.5

Low superstructure elevation: USLAB * DSLAB USRAB DSRAB Benchmark location description:

BM\#1, spike in pole, 25 feet from left bank on TH7 and 15' off the right side of the roadway, elevation 500.00. BM\#2, 8 inch cherry tree, 130 feet from right bank on TH 7 and 15 feet of the left side of the road.

Reference Point (MSL, Arbitrary, Other): Arbitrary D Datum (NAD27, NAD83, Other): Arbitrary Foundation Type: 1 (1-Spreadfooting; 2-Pile; 3- Gravity; 4-Unknown)

If 1 : Footing Thickness $\mathbf{2 . 0} \quad$ Footing bottom elevation: $\underline{\mathbf{4 8 8 . 2 5}}$

If 2: Pile Type: ___ (1-Wood; 2-Steel or metal; 3-Concrete) Approximate pile driven length: -

If 3: Footing bottom elevation: -

Is boring information available? $\mathrm{N}$ If no, type ctrl- $n$ bi Number of borings taken: _-

Foundation Material Type: $\mathbf{3}$ (1-regolith, 2-bedrock, 3-unknown)

Briefly describe material at foundation bottom elevation or around piles:

There is no foundation material information available.

Comments:

Plans indicate a right abutment footing bottom elevation of 488.25 feet while that for the left abutment is 488.00 feet. Hydraulic data entered above is from structural report and bridge plans. An updated copy of elevation bridge drawing has all elevations exactly one foot lower than the elevation values entered above.

*Other elevation points are at the top of upstream wingwalls 502.58 left and 502.83 right. 


\section{Cross-sectional Data}

Is cross-sectional data available? $\underline{\mathbf{Y}}$

If no, type ctrl-n xs

Source (FEMA, VTAOT, Other)? VTAOT

Channel cross section surveyed 75 feet from the downstream bridge face. The channel base

Comments: line CBL(0) runs along the left bank parallel to the stream 26 feet from the left abutment; nearly parallel to the abutment wall.

\begin{tabular}{|l|l|l|l|l|l|l|l|l|l|l|l|}
\hline Station & -20 & -10 & 0 & 10 & 13 & 18 & 25 & 35 & 53 & 65 & 69 \\
\hline Feature & HLB & & CBL & TLB & LEW & & & TD & & REW & TRB \\
\hline $\begin{array}{l}\text { Low chord } \\
\text { elevation }\end{array}$ & & & & & & & & & & & \\
\hline $\begin{array}{l}\text { Bed } \\
\text { elevation }\end{array}$ & 497.5 & 498.0 & 498.3 & 497.8 & 495.0 & 492.1 & 489.2 & 487.0 & 491.6 & 495.0 & 498.0 \\
\hline $\begin{array}{l}\text { Low chord- } \\
\text { bed }\end{array}$ & & & & & & & & & & & \\
\hline Station & 79 & & & & & & & & & & \\
\hline Feature & HRB & & & & & & & & & & \\
\hline $\begin{array}{l}\text { Low chord } \\
\text { elevation }\end{array}$ & & & & & & & & & & & \\
\hline $\begin{array}{l}\text { Bed } \\
\text { elevation }\end{array}$ & 498.7 & & & & & & & & & & VTA \\
\hline $\begin{array}{l}\text { Low chord- } \\
\text { bed }\end{array}$ & & & & & & & & & & & OT \\
\hline
\end{tabular}

Source (FEMA, VTAOT, Other)? Channel

Comments: section surveyed 25 feet from the downstream bridge face.

\begin{tabular}{|l|l|l|l|l|l|l|l|l|l|l|l|}
\hline Station & -13 & 0 & 15 & 19 & 20 & 43 & 50 & 60 & 64 & 67 & \\
\hline Feature & HLB & CBL & TLB & LEW & & & TD & & REW & TRB & \\
\hline $\begin{array}{l}\text { Low chord } \\
\text { elevation }\end{array}$ & & & & & & & & & & & \\
\hline $\begin{array}{l}\text { Bed } \\
\text { elevation }\end{array}$ & 497.9 & 496.1 & 497.4 & 495.0 & 493.3 & 488.1 & 487.0 & 490.5 & 495.0 & 498.0 & \\
\hline $\begin{array}{l}\text { Low chord- } \\
\text { bed }\end{array}$ & & & & & & & & & & & \\
\hline Station & & & & & & & & & & & \\
\hline Feature & & & & & & & & & & & \\
\hline $\begin{array}{l}\text { Low chord } \\
\text { elevation }\end{array}$ & & & & & & & & & & & \\
\hline $\begin{array}{l}\text { Bed } \\
\text { elevation }\end{array}$ & & & & & & & & & & & \\
\hline $\begin{array}{l}\text { Low chord- } \\
\text { bed }\end{array}$ & & & & & & & & & & & \\
\hline
\end{tabular}




\section{APPENDIX E: \\ LEVEL I DATA FORM}


U. S. Geological Survey

Bridge Field Data Collection and Processing Form

Qa/Qc Check by: EW Date: $\underline{\mathbf{0 3} / \mathbf{0 5} / 96}$

\section{Structure Number MAIDTH0007004}

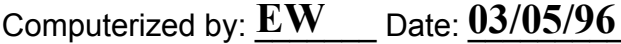

Reviewd by: LKS Date: $\underline{\mathbf{0 8 / 1 2 / 9 7}}$

\section{A. General Location Descriptive}

1. Data collected by (First Initial, Full last name) L. MEDALIE

Date $(M M / D D / Y Y) \quad 07 / 19 / 1995$

2. Highway District Number $\mathbf{0 7}$

County Essex (009)

Waterway (I - 6) Cutler Mill Brook

Route Number $\mathbf{\text { TH007 }}$

3. Descriptive comments:

The bridge is located 0.2 miles from the junction of Town Highway 7 and Town Highway 4.
Mile marker -

Town Maidstone (42475)

Road Name -

Hydrologic Unit Code: $\mathbf{0 1 0 8 0 1 0 1}$

\section{B. Bridge Deck Observations}
4. Surface cover... LBUS 5
RBUS 5
LBDS 5
RBDS 5
Overall 5

(2b us, ds,lb,rb: 1- Urban; 2- Suburban; 3- Row crops; 4- Pasture; 5- Shrub- and brushland; 6- Forest; 7- Wetland)
5. Ambient water surface... US 1
UB 1
DS 1
(1- pool; 2- riffle)

6. Bridge structure type 1 (1- single span; 2- multiple span; 3- single arch; 4- multiple arch; 5-cylindrical culvert; 6- box culvert; or 7- other)

7. Bridge length 25 (feet)

\section{Road approach to bridge:}
8. LB 0
RB 2
( 0 even, 1- lower, 2- higher)
9. LB_2
RB $\underline{2}$
(1- Paved, 2- Not paved)

10. Embankment slope (run / rise in feet / foot)

$$
\text { US left }
$$

2.7:1

US right

5.6:1

\begin{tabular}{|c|c|c|c|c|}
\hline & \multicolumn{2}{|c|}{ Protection } & \multirow{2}{*}{ 13.Erosion } & \multirow{2}{*}{ 14.Severity } \\
\hline & 11.Type & 12.Cond. & & \\
\hline LBUS & 0 & - & $\mathbf{0}$ & - \\
\hline RBUS & 2 & 1 & 2 & 1 \\
\hline RBDS & $\mathbf{0}$ & - & $\mathbf{0}$ & - \\
\hline LBDS & $\mathbf{0}$ & - & $\mathbf{0}$ & - \\
\hline
\end{tabular}

Bank protection types: $\mathbf{0}$ - none; $\mathbf{1}-<12$ inches;

2- < 36 inches; 3- < 48 inches;

4- < 60 inches; 5- wall / artificial levee

Bank protection conditions: 1- good; 2- slumped;

3- eroded; 4- failed

Erosion: 0 - none; 1- channel erosion; 2-

road wash; 3- both; 4- other

Erosion Severity: 0 - none; 1- slight; 2- moderate; 3- severe
Span length 22
(feet)
Bridge width 20 (feet)

\section{Channel approach to bridge (BF):}

15. Angle of approach: $\mathbf{2 0}$

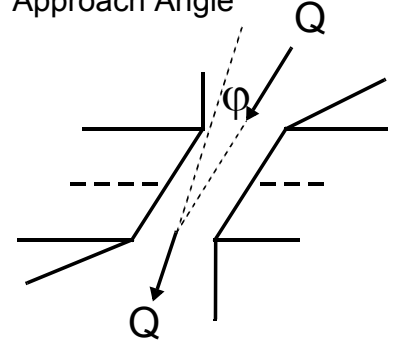

17. Channel impact zone 1:

Where? LB (LB, RB)

Range? 0 feet $\underline{\text { US }}$

Channel impact zone 2:

Where? LB $(L B, R B)$

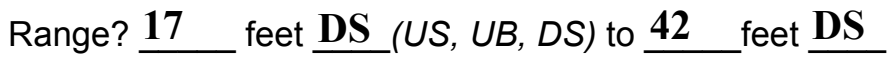

Impact Severity: 0- none to very slight; 1- Slight; 2- Moderate; 3- Severe
16. Bridge skew: 20 Bridge Skew Angle

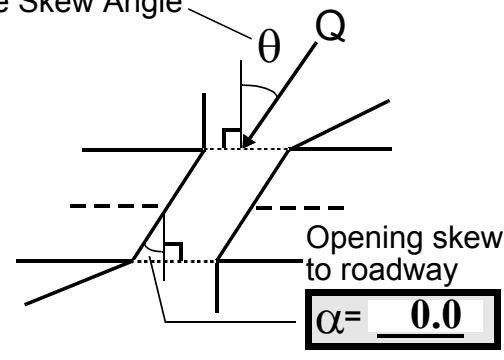

\section{Exist? $\mathbf{Y}(Y$ or $N)$}

Severity 1

US, UB, DS) to $\underline{\mathbf{2 5}}$ feet $\underline{\mathbf{U S}}$

Exist? $\mathbf{Y}(Y$ or $N)$

Severity $\underline{\mathbf{0}}$ 
18. Bridge Type: 4

1a- Vertical abutments with wingwalls

$1 \mathrm{~b}$ - Vertical abutments without wingwalls

2- Vertical abutments and wingwalls, sloping embankment Wingwalls parallel to abut. face

3- Spill through abutments

4- Sloping embankment, vertical wingwalls and abutments

Wingwall angle less than $90^{\circ}$.

19. Bridge Deck Comments (surface cover variations, measured bridge and span lengths, bridge type variations,

approach overflow width, etc.)

\#4: There is pasture on the LBUS after 30 feet width of brush. There are some trees on the right bank downstream and the right bank upstream.

\#7: Bridge dimensions measured values: bridge length= 25 feet; span length= 21.7 feet; bridge width $=\mathbf{2 1 . 6}$ feet

\#8: Water will flow over bridge deck first, then road on both sides. Refer to roadway survey log for clarification.

\section{Upstream Channel Assessment}

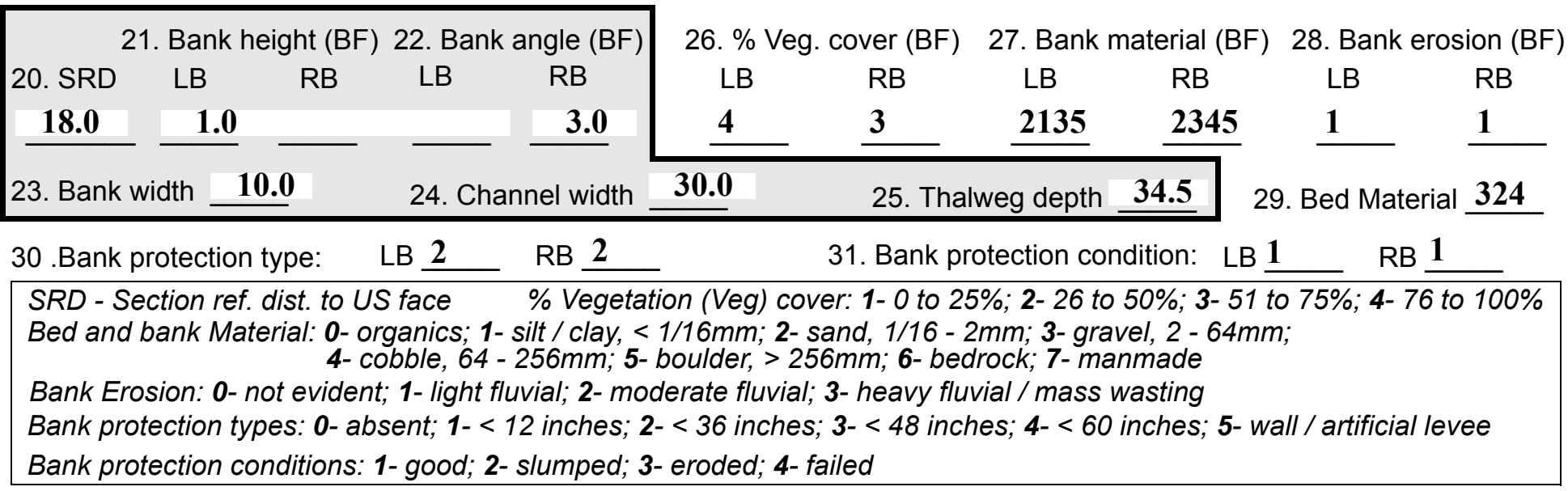

32. Comments (bank material variation, minor inflows, protection extent, etc.):

\#26: Although vegetation is brush, it is considered an obstruction to flow since it is 10-15 feet tall and has significant root mass.

\#28: The bank erosion is very slight.

\#30: There are some large boulders along the LB placed as protection. 
33.Point/Side bar present? $\mathbf{N}(Y$ or $N$. if $N$ type ctrl-n pb)34. Mid-bar distance: -

35. Mid-bar width: -

36. Point bar extent: feet (US, UB) to feet (US, UB, DS) positioned $\%$ LB to $\% \mathrm{RB}$

37. Material: -

38. Point or side bar comments (Circle Point or Side; Note additional bars, material variation, status, etc.):

There are no point bars upstream at this site.

39. Is a cut-bank present? $\underline{\mathbf{N}}$ (Y or if $\mathrm{N}$ type ctrl-n cb)

40. Where? - $\quad$ (LB or RB)

41. Mid-bank distance: -

42. Cut bank extent: feet (US, UB) to feet (US, UB, DS)

43. Bank damage: (1- eroded and/or creep; 2- slip failure; 3- block failure)

44. Cut bank comments (eg. additional cut banks, protection condition, etc.):

There are no cut-banks upstream at this site.

\section{Is channel scour present? $\mathbf{N}$ ( $Y$ or if $N$ type ctrl-n cs)}

47. Scour dimensions: Length Width Depth : 46. Mid-scour distance: -

48. Scour comments (eg. additional scour areas, local scouring process, etc.):

There is no channel scour upstream at this site.

Scour begins 5 feet US and extends DS, refer to DS assessment.

\section{Are there major confluences? $\mathbf{N}$} (Y or if $N$ type ctrl-n $m c)$

51. Confluence 1: Distance Confluence 2: Distance 52. Enters on (LB or $R B)$ Enters on (LB or $R B)$

54. Confluence comments (eg. confluence name):

There are no major confluences upstream at this site.

\section{Under Bridge Channel Assessment}

55. Channel restraint (BF)? LB 2 (1- natural bank; 2- abutment; 3- artificial levee)

\begin{tabular}{|ccccc}
\multicolumn{2}{|c}{56. Height (BF) } & \multicolumn{3}{c}{57 Angle (BF) } \\
LB & RB & LB & RB \\
$\mathbf{2 3 . 0}$ & & & $\mathbf{3 . 0}$ & \\
\hline
\end{tabular}

58. Bank width (BF) -

59. Channel width 61. Material (BF) LB RB 62. Erosion (BF)

$2 \quad 7$
LB RB

Bed and bank Material: 0- organics; 1- silt / clay, < 1/16mm; 2- sand, 1/16 - 2mm; 3- gravel, 2 - 64mm; 4- cobble, 64 - 256mm; 5- boulder, > 256mm; 6- bedrock; 7- manmade

Bank Erosion: 0- not evident; 1- light fluvial; 2- moderate fluvial; 3- heavy fluvial / mass wasting

64. Comments (bank material variation, minor inflows, protection extent, etc.):

324

\#63: The bed material grades from sand at the right abutment to gravel and cobble at the left abutment. 
65. Debris and Ice Is there debris accumulation?

$(Y$ or $N)$ 66. Where? $\mathbf{N}$

(1- Upstream; 2- At bridge; 3- Both)

67. Debris Potential ( 1- Low; 2- Moderate; 3- High)

68. Capture Efficiency 1 (1-Low; 2- Moderate; 3- High)

69. Is there evidence of ice build-up? 2 (Y or $N)$

Ice Blockage Potential $\mathbf{N}$

(1-Low; 2- Moderate; 3- High)

70. Debris and Ice Comments:

1

Capture efficiency is rated as moderate since the span width is $1 / 2$ the average bank width.

\begin{tabular}{|l|c|c|c|c|c|c|c|c|}
\hline Abutments & $\begin{array}{c}\text { 71. Attack } \\
\angle \mathrm{BF})\end{array}$ & $\begin{array}{c}\text { 72. Slope } \\
(\mathrm{Qmax})\end{array}$ & $\begin{array}{l}\text { 73. Toe } \\
\text { loc. (BF) }\end{array}$ & $\begin{array}{c}\text { 74. Scour } \\
\text { Condition }\end{array}$ & $\begin{array}{c}\text { 75. Scour } \\
\text { depth }\end{array}$ & $\begin{array}{c}\text { 76. Exposure } \\
\text { depth }\end{array}$ & 77. Material & 78. Length \\
\hline LABUT & & $\mathbf{2 0}$ & $\mathbf{9 0}$ & $\mathbf{0}$ & $\mathbf{1}$ & $\mathbf{2}$ & - & $\mathbf{9 0 . 0}$ \\
\hline RABUT & $\mathbf{1}$ & $\mathbf{0}$ & $\mathbf{9 0}$ & & & $\mathbf{0}$ & $\mathbf{0}$ & $\mathbf{2 1 . 5}$ \\
\hline
\end{tabular}

Pushed: $L B$ or RB

Toe Location (Loc.): 0- even, 1- set back, 2- protrudes

Scour cond.: 0- not evident; 1- evident (comment); 2- footing exposed; 3-undermined footing; 4- piling exposed; 5- settled; 6- failed

Materials: 1- Concrete; 2- Stone masonry or drywall; 3- steel or metal; 4- wood

79. Abutment comments (eg. undermined penetration, unusual scour processes, debris, etc.):

$-$

1

\#74-75: At LABUT, the bed is as deep as 5 feet, which is 2 feet deeper than average US and DS thalweg.

80. Wingwalls:

Exist? Material? Scour Scour Exposure $\begin{aligned} & 81 . \\ & \text { Angle? Length? }\end{aligned}$

USLWW: Condition? depth? depth?
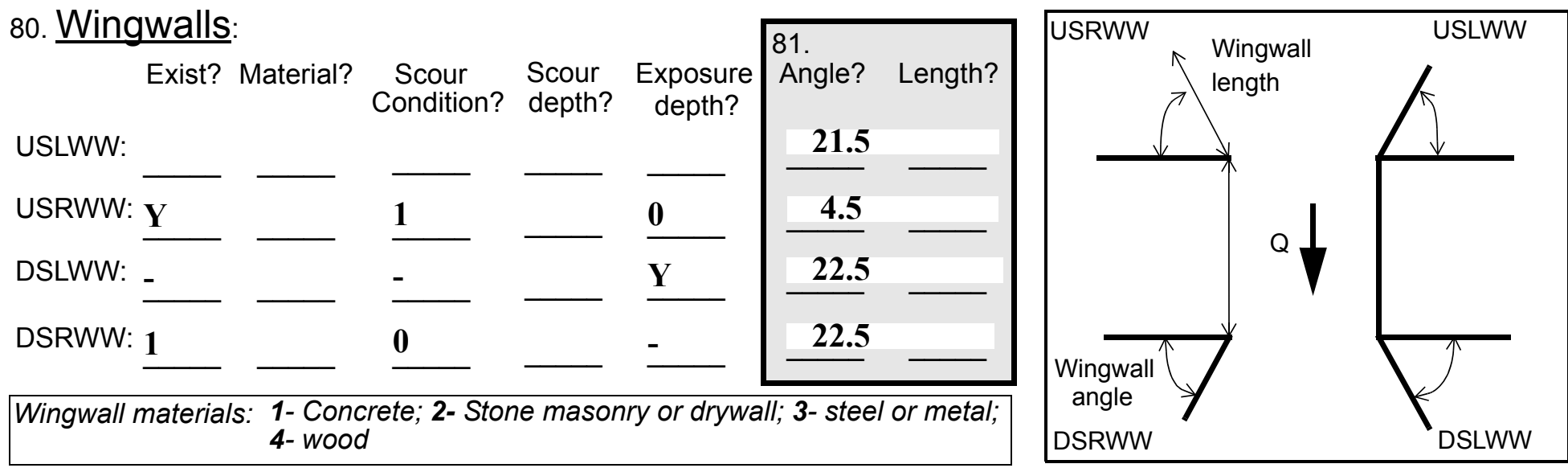

82. Bank / Bridge Protection:

\begin{tabular}{|l|l|l|l|l|l|l|l|l|}
\hline Location & USLWW & USRWW & LABUT & RABUT & LB & RB & DSLWW & DSRWW \\
\hline Type & - & $\mathbf{0}$ & $\mathbf{Y}$ & - & $\mathbf{1}$ & $\mathbf{1}$ & - & - \\
\hline Condition & $\mathbf{Y}$ & - & $\mathbf{1}$ & - & $\mathbf{1}$ & $\mathbf{2}$ & - & - \\
\hline Extent & $\mathbf{1}$ & - & $\mathbf{0}$ & $\mathbf{2}$ & $\mathbf{2}$ & $\mathbf{0}$ & - & - \\
\hline
\end{tabular}

Bank / Bridge protection types: 0- absent; 1- < 12 inches; 2- < 36 inches; 3- < 48 inches; 4- < 60 inches; 
83. Wingwall and protection comments (eg. undermined penetration, unusual scour processes, etc.):

$-$

$-$

$-$

$-$

0

-

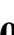

0

\section{Piers:}

84. Are there piers? \#82 (Y or if $N$ type ctrl-n pr)

\begin{tabular}{|l|l|l|l|l|l|l|l|}
\hline $\begin{array}{l}85 . \\
\text { Pier no. }\end{array}$ & \multicolumn{3}{|c|}{ width (w) feet } & \multicolumn{3}{c|}{ elevation (e) feet } \\
\cline { 2 - 8 } & w1 & w2 & w3 & e@w1 & e@w2 & e@w3 \\
\hline Pier 1 & & & & $\mathbf{4 5 . 0}$ & $\mathbf{1 2 . 0}$ & $\mathbf{4 0 . 0}$ \\
\hline Pier 2 & & & & $\mathbf{1 1 . 5}$ & $\mathbf{4 5 . 0}$ & $\mathbf{1 1 . 5}$ \\
\hline Pier 3 & & & - & $\mathbf{4 5 . 0}$ & $\mathbf{1 1 . 5}$ & - \\
\hline Pier 4 & - & - & - & - & - & - \\
\hline
\end{tabular}

\begin{tabular}{|l|l|l|l|l|}
\hline Level 1 Pier Descr. & \multicolumn{1}{|c|}{1} & \multicolumn{1}{|c|}{2} & 3 & 4 \\
\hline 86. Location (BF) & :There & wall & & - \\
\hline 87. Type & are a & and & & - \\
\hline 88. Material & few & dow & & - \\
\hline 89. Shape & boul- & nstre & & - \\
\hline 90. Inclined? & ders & am & & - \\
\hline 91. Attack $\angle$ (BF) & in & left & & - \\
\hline 92. Pushed & front & wing & N & - \\
\hline 93. Length (feet) & - & - & - & - \\
\hline 94. \# of piles & of & wall. & - & - \\
\hline 95. Cross-members & upst & & - & - \\
\hline 96. Scour Condition & ream & & - & - \\
\hline 97. Scour depth & right & & - & - \\
\hline 98. Exposure depth & wing & & - & - \\
\hline
\end{tabular}

LFP, LTB, LB, MCL, MCM, MCR, RB, RTB, RFP

1- Solid pier, 2-column, 3- bent

1-Wood; 2- concrete; 3- metal; 4- stone

1- Round; 2- Square; 3- Pointed

Y-yes; $N$ - no

$L B$ or $R B$

0- none; 1- laterals; 2- diagonals; 3- both

0- not evident; 1- evident (comment);

2- footing exposed; 3- piling exposed;

4- undermined footing; 5- settled; 6-failed 
99. Pier comments (eg. undermined penetration, protection and protection extent, unusual scour processes, etc.):

-
-
-
-
-
-
-
-
-
-

100.

\section{E. Downstream Channel Assessment}

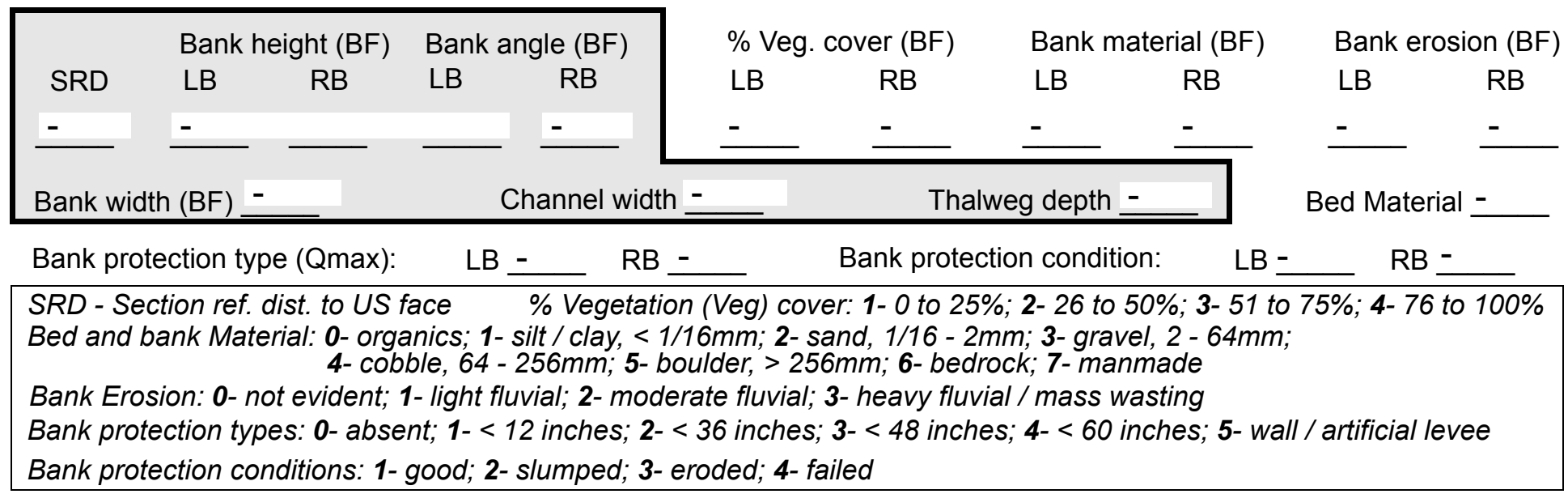

Comments (eg. bank material variation, minor inflows, protection extent, etc.):

-

There are no piers.

101. Is a drop structure present? ( $Y$ or $N$, if $N$ type ctrl-n ds)
102. Distance: - feet (1- steel sheet pile; 2- wood pile; 3- concrete; 4- other)
103. Drop: - feet 104. Structure material:

105. Drop structure comments (eg. downstream scour depth): 
Point bar extent: $\underline{\mathbf{2 3 4}}$ feet $\underline{\mathbf{0}}$ (US, UB, DS) to $\underline{\mathbf{0}}$ feet (US, UB, DS) positioned $\%$ LB to $\underline{\text { Th }} \%$ RB

Material: $\mathbf{e}$

Point or side bar comments (Circle Point or Side; note additional bars, material variation, status, etc.):

bed material grades from sand along RB to gravel and cobble at LB.

There is a minor inflow at 42 feet DS along $L B$. The confluence is 2 feet across and 1-2 feet high.

Is a cut-bank present? (Y or if $N$ type ctrl-n cb) Where? (LB or $R B)$

Mid-bank distance:

Cut bank extent: feet (US, UB, DS) to feet (US, UB, DS)

Bank damage: (1- eroded and/or creep; 2- slip failure; 3- block failure)

Cut bank comments (eg. additional cut banks, protection condition, etc.):

$\mathbf{N}$

Is channel scour present? ___ (Y or if N type ctrl- $n c s) \quad$ Mid-scour distance: Ther Scour dimensions: Length $\underline{\mathbf{e} \text { is }}$ Width no Depth: $\underline{\text { dro }} \quad$ Positioned $\underline{\mathbf{p}}$ \%LB to $\underline{\mathbf{s t r u}} \% \mathrm{RB}$ Scour comments (eg. additional scour areas, local scouring process, etc.):

cture.

A beaver dam exists about 400 feet DS. The dam is $40 \mathrm{ft}$ wide and has created a flooded area to the right of Are there major confluences? na ( $Y$ or if $N$ type ctrl-n $m c$ ) How many? tural Confluence 1: Distance strea Confluence 2: Distance ut Enters on $\underline{\mathbf{m}}$ (LB or $R B)$ Type abo (1- perennial; 2- ephemeral) Confluence comments (eg. confluence name): in diameter.

\section{F. Geomorphic Channel Assessment}

1- Constructed

2- Stable

3- Aggraded

4- Degraded

5- Laterally unstable

6- Vertically and laterally unstable 
108. Evolution comments (Channel evolution not considering bridge effects; See HEC-20, Figure 1 for geomorphic descriptors):

70

12

55

DS

140

DS

60

100

23

Bar grades into area with permanent vegetation. 


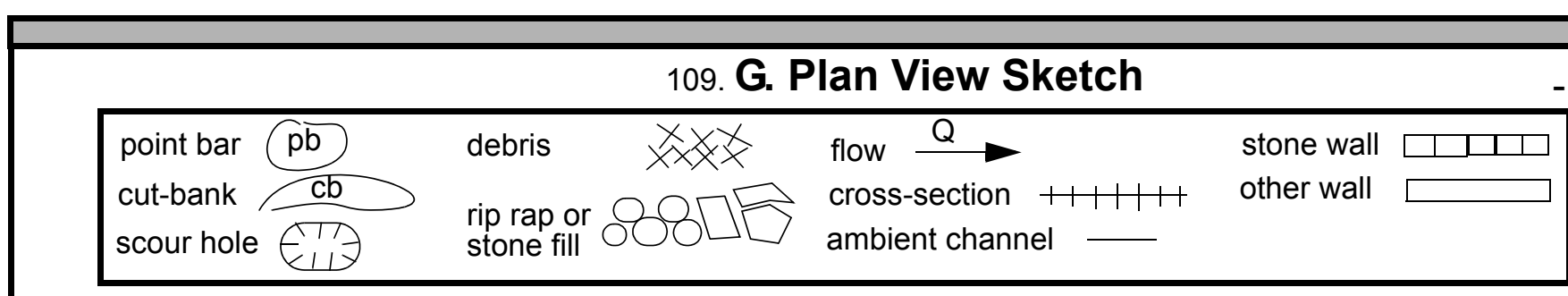


APPENDIX F:

SCOUR COMPUTATIONS 
SCOUR COMPUTATIONS

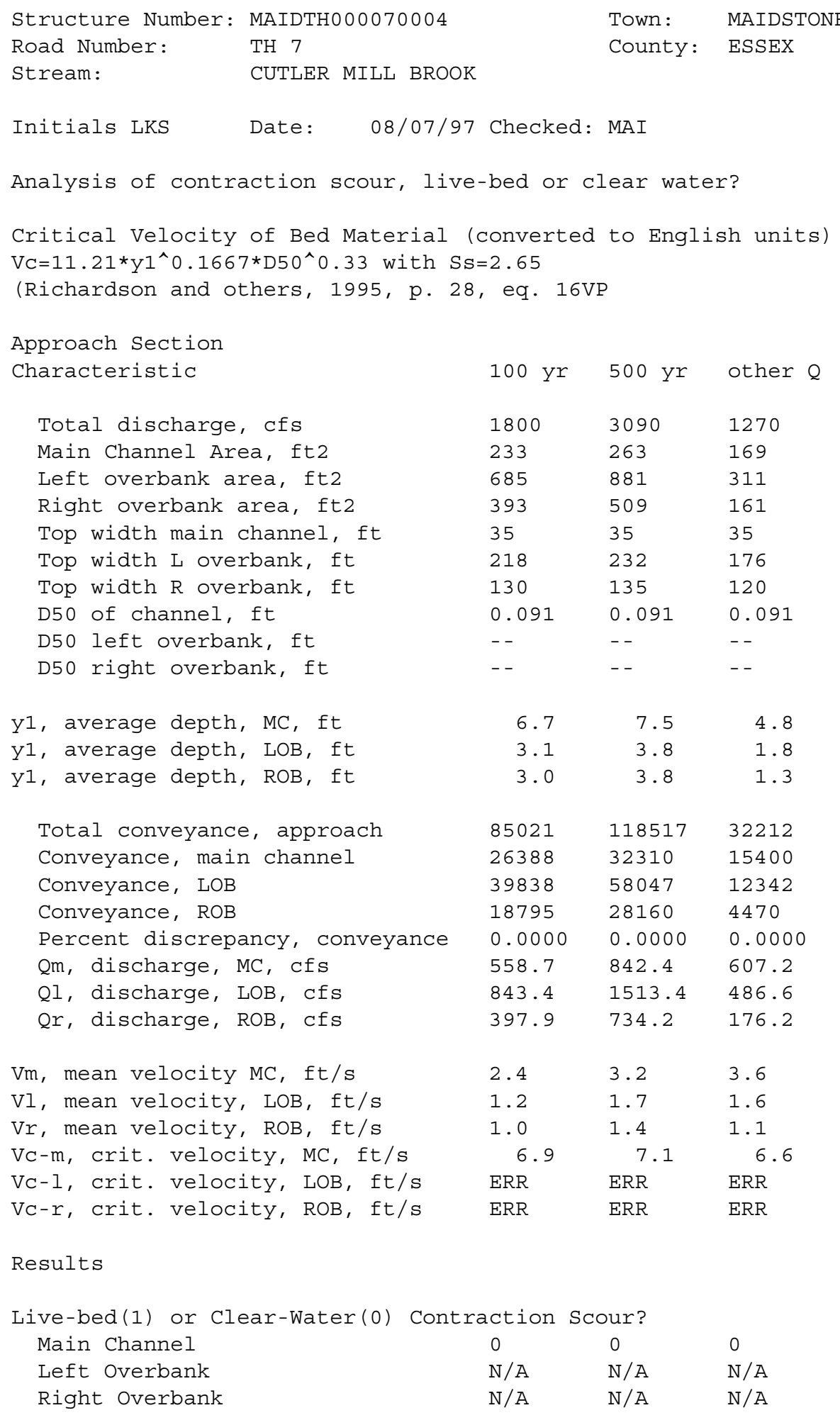


Clear water Contraction Scour in MAIN CHANNEL

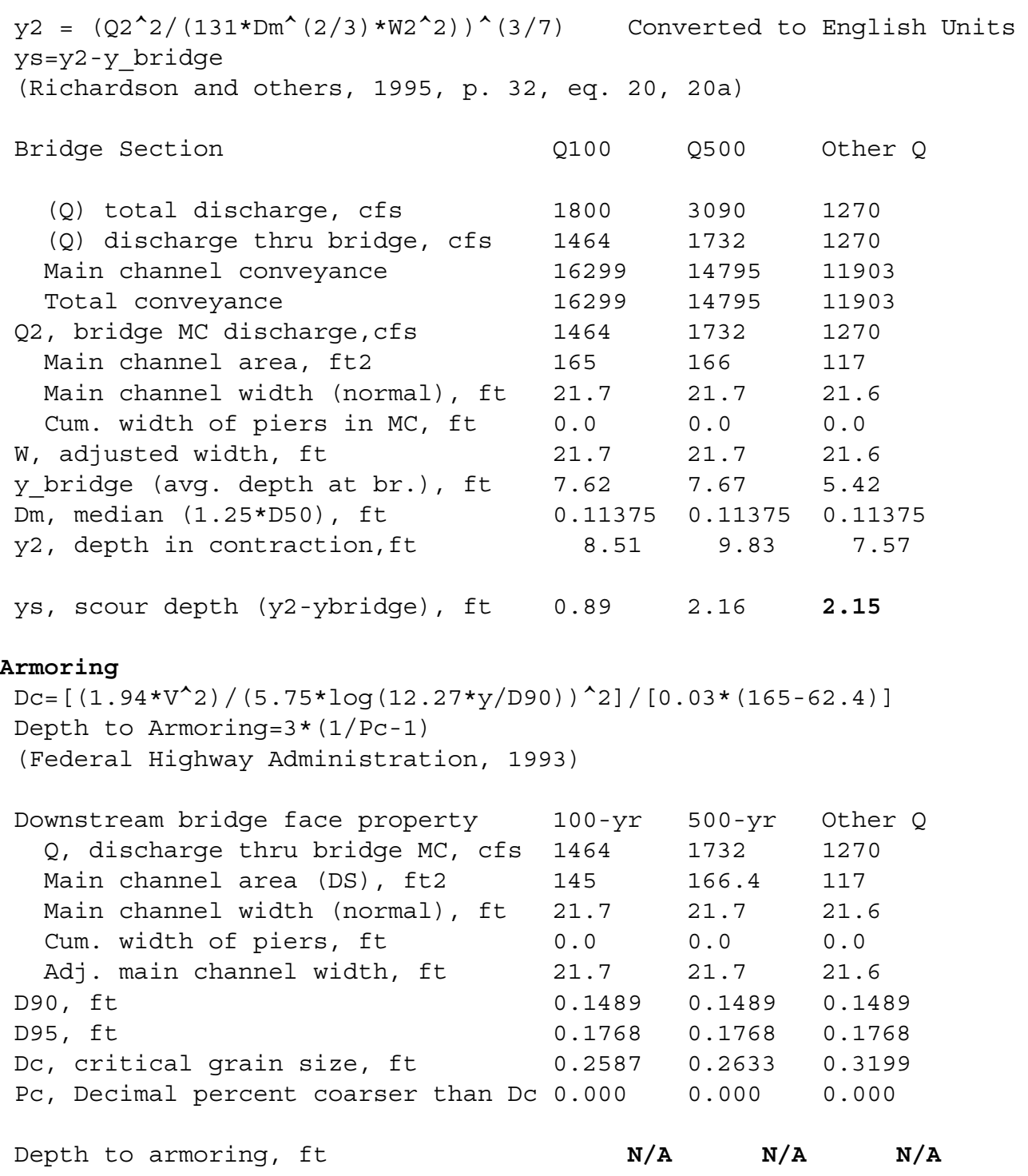


Pressure Flow scour (contraction scour for orifice flow conditions)

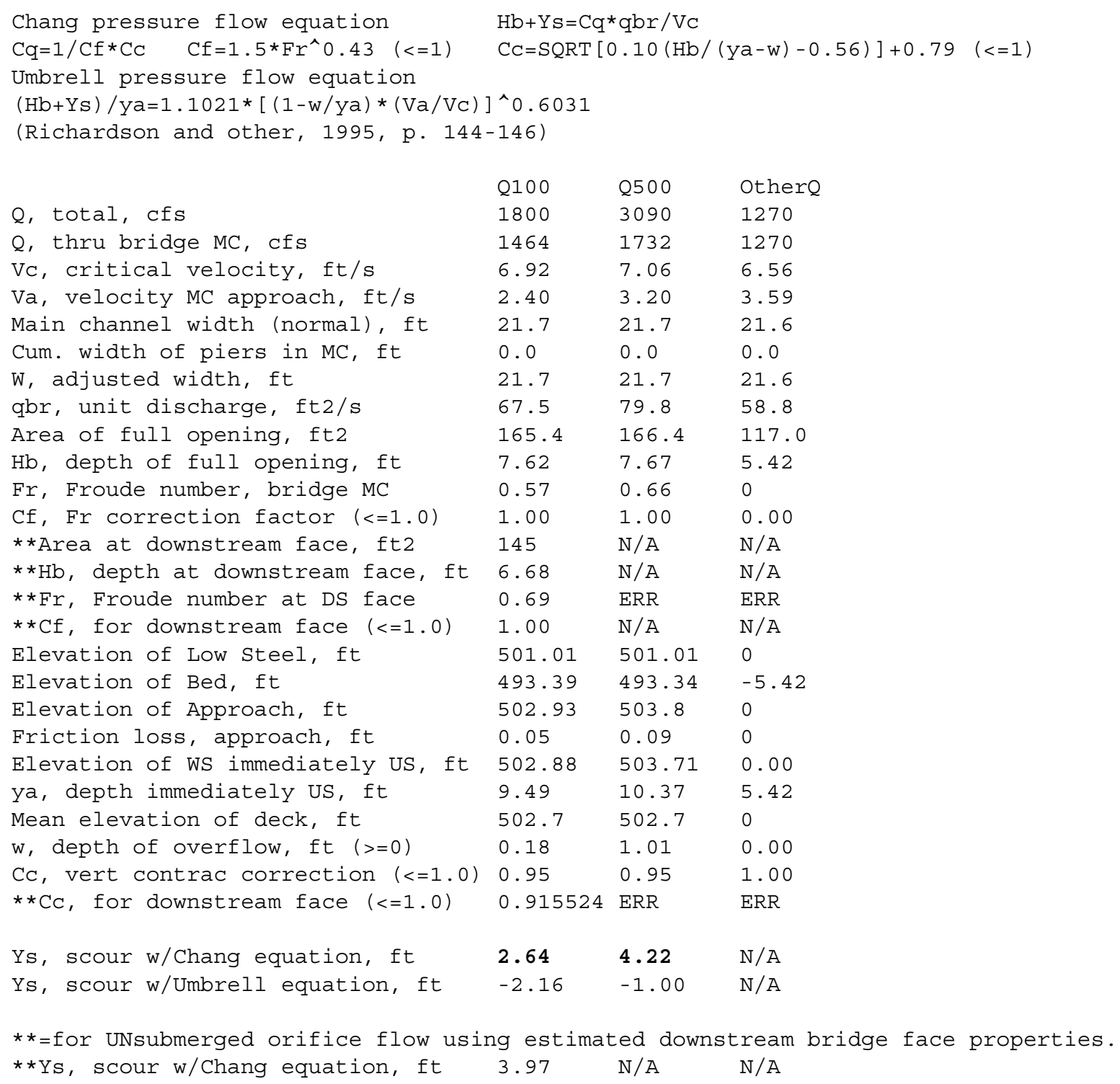




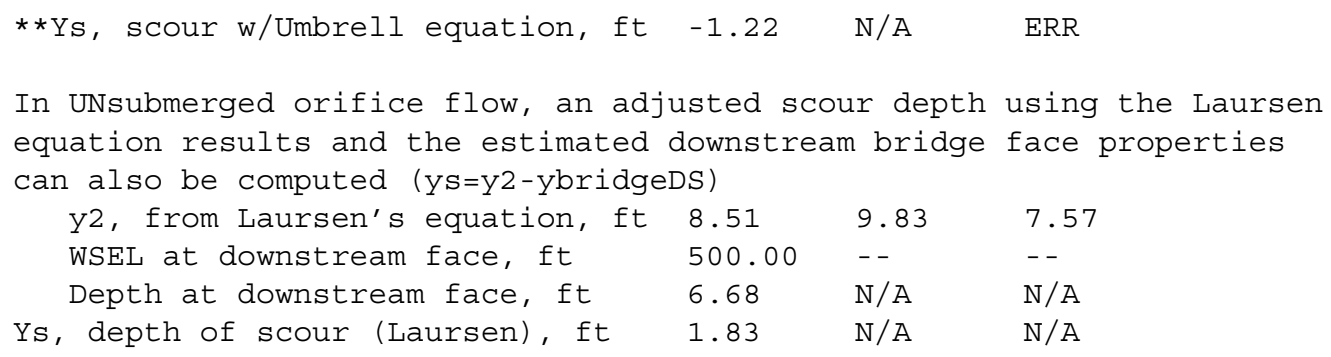

\section{Abutment Scour}

Froehlich's Abutment Scour

$\mathrm{Ys} / \mathrm{Y} 1=2.27 * \mathrm{~K} 1 * \mathrm{~K} 2 *\left(\mathrm{a}^{\prime} / \mathrm{Y} 1\right)^{\wedge} 0.43 * \mathrm{Fr} 1^{\wedge} 0.61+1$

(Richardson and others, 1995, p. 48, eq. 28)

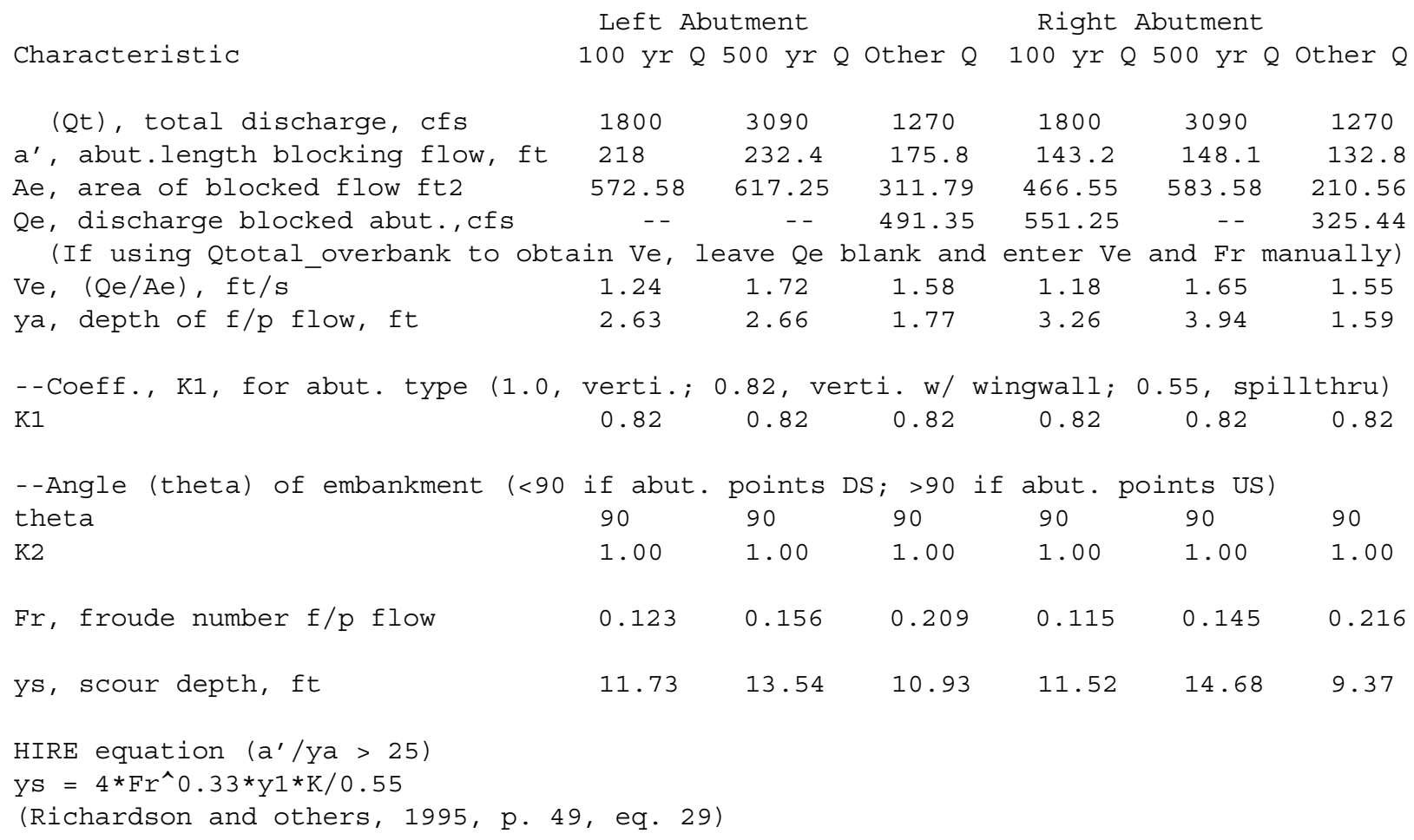




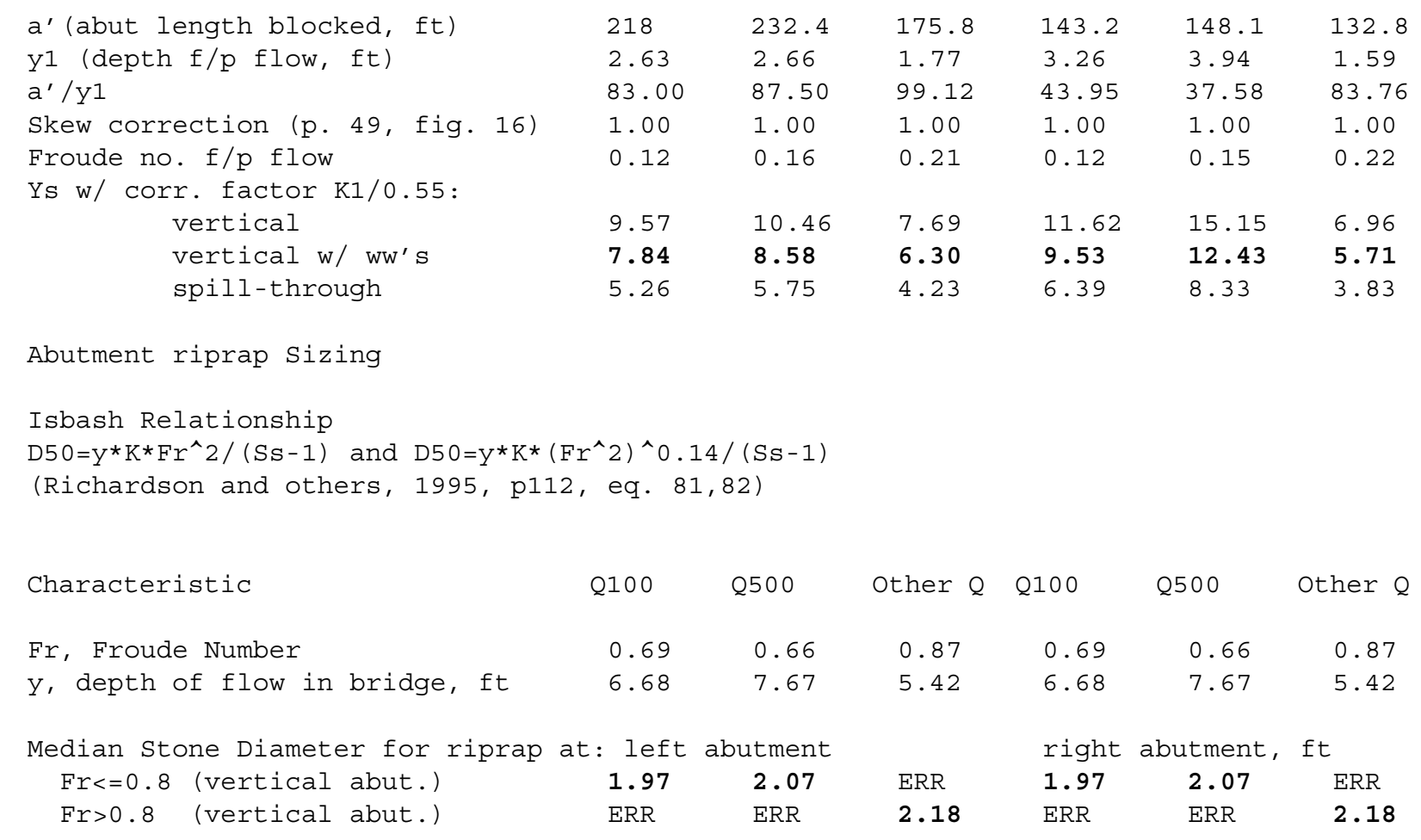

